\title{
Prion disease: experimental models and reality
}

\author{
Sebastian Brandner ${ }^{1}\left(\mathbb{D} \cdot\right.$ Zane Jaunmuktane $^{1}$
}

Received: 30 November 2016 / Revised: 4 January 2017 / Accepted: 5 January 2017 / Published online: 13 January 2017

(c) The Author(s) 2017. This article is published with open access at Springerlink.com

\begin{abstract}
The understanding of the pathogenesis and mechanisms of diseases requires a multidisciplinary approach, involving clinical observation, correlation to pathological processes, and modelling of disease mechanisms. It is an inherent challenge, and arguably impossible to generate model systems that can faithfully recapitulate all aspects of human disease. It is, therefore, important to be aware of the potentials and also the limitations of specific model systems. Model systems are usually designed to recapitulate only specific aspects of the disease, such as a pathological phenotype, a pathomechanism, or to test a hypothesis. Here, we evaluate and discuss model systems that were generated to understand clinical, pathological, genetic, biochemical, and epidemiological aspects of prion diseases. Whilst clinical research and studies on human tissue are an essential component of prion research, much of the understanding of the mechanisms governing transmission, replication, and toxicity comes from in vitro and in vivo studies. As with other neurodegenerative diseases caused by protein misfolding, the pathogenesis of prion disease is complex, full of conundra and contradictions. We will give here a historical
\end{abstract}

Electronic supplementary material The online version of this article (doi:10.1007/s00401-017-1670-5) contains supplementary material, which is available to authorized users.

Sebastian Brandner

s.brandner@ucl.ac.uk

Zane Jaunmuktane

z.jaunmuktane@ucl.ac.uk

1 Department of Neurodegenerative Disease, UCL Institute of Neurology and Division of Neuropathology, The National Hospital for Neurology and Neurosurgery, University College London Hospitals NHS Foundation Trust, Queen Square, London WC1N 3BG, UK overview of the use of models of prion disease, how they have evolved alongside the scientific questions, and how advancements in technologies have pushed the boundaries of our understanding of prion biology.

\section{Glossary}

Cellular prion protein $\left(\mathrm{PrP}^{\mathrm{C}}\right)$ : Native, host-encoded, detergent soluble, protease-sensitive glycoprotein tethered to the cell membrane by a glycosylphosphatidylinositol (GPI) anchor. $\operatorname{PrP}^{\mathrm{C}}$ is encoded by the PRNP gene in humans and the Prnp gene in mice. It has predominantly $\alpha$-helical structure, and it is expressed at high levels in the brain.

Disease-associated prion protein $\left(\mathrm{PrP}^{\mathrm{Sc}}\right)$ : Misfolded, post-translationally modified (abnormal) isoform of $\operatorname{PrP}^{\mathrm{C}}$, with a substantial $\beta$-sheet content. It is insoluble in non-denaturating agents and shows partial protease resistance.

Prions: Operational term to denote the transmissible agent of prion disease. According to the protein-only hypothesis, an essential constituent of prions is $\mathrm{PrP}^{\mathrm{Sc}}$.

Prion strains: Self-propagating prion protein conformations or assembly states. They are characterised by distinct neuropathological and biochemical profiles that can be maintained even after passage through an intermediate mammalian species with a different PrP aminoacid sequence.

Species barrier/transmission barrier: Barrier that limits cross-species infection, resulting in reduced transmission efficiency with lower attack rates and prolonged incubation periods.

Prion disease: Fatal neurodegenerative disorder, also known as transmissible spongiform encephalopathy, 
affecting humans and animals, characterised by accumulation of $\operatorname{PrP}^{\mathrm{Sc}}$ in the brain. Human prion diseases develop sporadically can be inherited due to germline mutations in the PRNP gene and can be acquired through infection with human or animal prions through various routes.

Creutzfeldt-Jakob Disease (CJD): Human prion disease usually presenting as a rapidly progressive neurological disorder with hallmark features of dementia, ataxia, and myoclonus.

Sporadic CJD (sCJD): The most common type of human prion diseases of unknown aetiology, occurring worldwide with an annual incidence of 1-2 cases per million. The phenotypic and neuropathological heterogeneity observed in SCJD is thought to be related to different prion strains and genetic factors, in particular the polymorphism on codon 129 of the PRNP gene.

Sporadic Fatal Insomnia (sFI): Clinical syndrome and neuropathology similar to FFI found in patients with PRNP 129MM genotype, but with absence of a D178N or any other mutation in the PRNP gene. First described in 1999.

Variably Proteinase-Sensitive Prionopathy (VPSPr): Sporadic prion disease of unknown aetiology first reported in 2008 with distinctive biochemical properties of $\mathrm{PrP}^{\mathrm{Sc}}$. In comparison with sCJD, $\mathrm{PrP}^{\mathrm{Sc}}$ in VPSPr is less resistant to protease digestion. Neuropathology of VPSPr includes microplaques in thalamus and cerebellum.

Iatrogenic CJD (iCJD): Acquired prion disease caused by transmission of prions through medical procedures and treatments with prion-contaminated human cadaveric derived growth hormone, dura mater or cornea, or neurosurgical instruments.

Kuru: Prion disease acquired through dietary exposure to prions through ritualistic cannibalism practiced mainly by the people of the Fore linguistic group, a population of the Eastern Highlands of Papua New Guinea. Clinically, it is characterised by progressive cerebellar ataxia and less prominently, dementia. Kuru peaked in the 1950s before cannibalism ceased.

Variant CJD (vCJD): Acquired prion disease due to dietary exposure to BSE prions first recognised in 1996. It is characterised by involvement of the lymphoreticular tissue and by a distinct neuropathological picture often presenting in young people, usually with a characteristic clinical phenotype.

Inherited prion diseases (IPD): They are caused by germ-line mutations in the PRNP gene and are inherited in autosomal dominant fashion with a high penetrance. They present as distinct clinical syndromes (GSS, FFI, and CJD) depending on the mutation.
Gerstmann-Sträussler-Scheinker disease (GSS): Inherited prion disease characterised clinically by adult-onset ataxia, postural abnormalities, and cognitive decline. It is named after three clinicians, who first reported the disorder in 1936. A proline-to-leucine substitution at codon 102 (P102L) of human PrP is the most common mutation associated with the GSS phenotype and was first reported in 1989.

Fatal Familial Insomnia (FFI): Inherited prion disease characterised clinically by disruption of the physiological sleep patterns and is associated with a thalamic degeneration. It is caused by a PRNP D178N mutation on the allele harbouring methionine at polymorphic codon 129. FFI was first described in 1986 and was successfully transmitted to mice in 1995.

Bovine spongiform encephalopathy (BSE): Prion disease in cattle. BSE was epidemic in the United Kingdom with a peak incidence in 1992. More than 180,000 cattle were infected. Transmission of BSE prions through dietary exposure caused vCJD in humans.

Scrapie: Prion disease in sheep, known for more than two centuries. Scrapie was the first transmitted prion disease and scrapie prions and strains derived thereof have since been widely used in experimental studies.

\section{Introduction}

Prion diseases are rare transmissible disorders, caused by misfolded post-translationally modified form of the native, host-encoded form of prion protein, designated $\operatorname{PrP}^{\mathrm{C}}[2$, 12]. It is proposed that the conversion of $\operatorname{PrP}^{\mathrm{C}}$ into an abnormal isoform, commonly termed $\mathrm{PrP}^{\mathrm{Sc}}$, is causally related to neurotoxicity, which is thought to be a result of a combination of toxic intermediates [157], overload of protein clearance pathways [106], and formation of protein aggregates [39].

The finding that the scrapie agent is infectious, transmissible, and resistant to proteinases, heat, and decontamination methods that modify nucleic acids and would normally kill any conventional microorganisms enabled Stanley Prusiner to formulate the protein-only hypothesis [146], previously proposed by Griffith [61] and to introduce the term "prion"- a small proteinaceous infectious particle devoid of nucleic acid. Subsequently, the PRNP gene and its product, $\operatorname{PrP}^{\mathrm{C}}$, were identified $[12,36,131]$. It is now widely accepted that $\mathrm{PrP}^{\mathrm{Sc}}$, the disease-associated isoform, aggregates and deposits in the brain, where it causes neurodegeneration. An enigmatic property of prions is the existence of strains which are associated with distinct neuropathological disease patterns and biochemical properties and are maintained through passages into different species, 
although often at a reduced efficiency, which has been termed species (or transmission) barrier [79]. Mutations in the open reading frame of the PRNP gene cause a spontaneous conversion of $\mathrm{PrP}^{\mathrm{C}}$ into the abnormal isoform and often result in neurodegenerative syndromes, but are not always transmissible.

This review will give an overview of the historical development of models of prion disease, which has been generated to address the multiple aspects of prion disease. We will put the models in the context of the available technology and the scientific questions at the time. The use of model systems for a human disease usually aims at addressing specific biological questions, rather than being comprehensive or being a faithful replica of the human disease. We will describe here for which aspects these models are useful and where they fail to give an answer. Many models have been generated to address a specific hypothesis rather than replicating an existing disease, and some raise more questions than they answer. Whilst certain aspects can be addressed by cell culture or in cell-free systems in vitro, animal models remain a mainstay in prion disease research, as only these allow to study clinical phenotypes, neuropathological characteristics, transmission barriers, and the role of pathogenic mutations. In this review, we will first present the most significant animal models that have been used for the study of prion disease. Genetically modified mice have given answers to many essential biological questions in prion disease and will, therefore, form a major part of this review. Then, we will briefly discuss ex vivo and in vitro studies. Some of the biological questions can only be addressed by a combination of animal models and methodologies and these are discussed in the second part of the review. The illustrations of this review then combine and integrate the systematic overview of the model systems with the biological question.

In this review, we will give the reader an overview, and a selection of references will provide guidance for further reading. It is not our aim and also not possible to give an entirely exhaustive list of references, and we, therefore, had to resort to citing the most commonly used models or approaches. Where necessary, we have given references to in-depth reviews on specific topics.

\section{Animal models of prion disease: from monkeys to flies}

\section{Transmission of human prion diseases into primates}

Inoculation of isolates of kuru and Creutzfeldt-Jakob disease (CJD) into primates [54, 55, 57] proved transmission of human prion diseases and provided a model for the reproduction of histological phenotypes of spongiform encephalopathy (Fig. 1). Even decades later, despite the growing importance of genetically modified mouse models, which provided increased versatility and better readout, primates continued to have a role in transmission studies: transmission of brain extracts from cattle with Bovine Spongiform Encephalopathy (BSE) into macaques established the first pathogenetic link between BSE and variant CJD (vCJD) [101], by producing a pathological phenotype that was nearly identical to vCJD. In more recent studies, primate models are used in correlative studies looking at transmission properties of different prion strains [135], to establish the zoonotic potential of transmissible spongiform encephalopathies (TSE) other than BSE, such as natural scrapie [46], to assess transfusion safety through application of specifically designed prion removal filters [104], or to estimate the risk of oral infection with the BSE agent [100]. Cynomolgus macaque monkey (Macaca fascicularis) has remained a relatively popular choice for prion research in primates, due to their longevity, phylogenetic proximity to humans, similar digestive physiology, and their genetic similarity to humans, including homozygosity for methionine at PRNP codon 129 . The main limitations for more experimental studies on primates are their expensive maintenance, duration of experiments, and ethical concerns.

\section{Rodents (hamsters, mice, and bank voles): modelling transmission, disease mechanisms, and function of PrP}

Hamsters used to be popular for many types of prion studies since the 1970 s, but were gradually replaced by mouse models, due to the widespread availability of genetically modified mice in the 1990 s, initially by transgenesis, followed by the combination with the gene knock-out model and, more recently, the inducible expression and deletion of the Prnp gene. A niche model, the bank vole will also be briefly discussed here (Fig. 2).

Wild-type Syrian golden hamsters have been used in prion research for over four decades with the first transmission experiments in the 1970s. Hamsters have been invaluable for the understanding of anatomical and functional pathways of prion spread from the periphery and within the CNS [75, 80, 81]. Through these models, distinct properties of different prion strains have been identified and they helped understanding the species barriers [78]. Although hamsters are still occasionally used in prion research, for example, for investigating the distribution and spread of prions after peripheral challenge [35], the wide availability and versatility of transgenic mouse models have made hamster models largely obsolete.

Bank voles, small rodents, have been added relatively recently to the models of prion research [29, 128]. Their susceptibility to prions originating from multiple different 


\begin{tabular}{|c|c|c|c|c|c|c|c|c|c|c|c|c|}
\hline \multirow{2}{*}{$\begin{array}{l}\text { First report of the } \\
\text { disease }\end{array}$} & \multirow{2}{*}{ Year } & \multicolumn{8}{|c|}{ Inocula } & \multirow{2}{*}{ Recipient } & \multirow{2}{*}{ Route } & \multirow{2}{*}{ Reference } \\
\hline & & Scrapie & Kuru & SCJD & IPD & ICJD & BSE & vCJD & VPSPr & & & \\
\hline & 2016 & & & & IPD」j & & & & & Wild type bank voles & IC & Pirisinu, 2016 \\
\hline & 2015 & Scrapie & & & & & & & & Macaque (Cynomolgus) & IC & Comoy, 2015 \\
\hline & 2015 & & & & & & BSE & vCJD & & Macaque (Cynomolgus) & Blood & Lescoutra-Etchegaray, 2015 \\
\hline & 2014 & & & & & & & & VPSPr & Tg (HuPrP129VV/MM/MV) mice & IC & Notari, 2014; Diack, 2014 \\
\hline & 2014 & Scrapie & & SCJD & & & BSE & vCJD & & $\mathrm{Tg}$ (bank vole PrP) mice & IC & Watts, 2014 \\
\hline & 2011 & Scrapie & & & & & & & & Wild type mice & Aerosol & Haybaeck, 2011 \\
\hline & 2011 & Scrapie & & & & & & & & $\operatorname{Tg}(\operatorname{Tg} 20 \mathrm{a})$ mice & Aerosol & Haybaeck, 2011 \\
\hline \multirow{14}{*}{$\begin{array}{c}\text { VPSPr } \\
\text { (Gambetti, 2008) }\end{array}$} & 2009 & & & & IPD_i & & & & & Tg (HuPrP-mut) mice* & IC & Asante, 2009 \\
\hline & 2008 & & Kuru & & & & & & & $\operatorname{Tg}$ (HuPrP129VV) mice & IC & Wadsworth, 2008 \\
\hline & 2006 & & & & IPD_h & & & & & $\operatorname{Tg}$ (HuPrP129VV) mice & IC & Mead, 2006 \\
\hline & 2006 & & & & & & & vCJD & & $\mathrm{Tg}$ (HuPrP129VV/MM/MV) mice & IC & Bishop, 2006 \\
\hline & 2006 & & & & & & & vCJD & & $\operatorname{Tg}$ (HuPrP129MM/MV) mice & IC & Asano, 2006 \\
\hline & 2006 & & & & & & & VCJD & & $\mathrm{Tg}$ (HuPrP129MV) mice & IC & Asante, 2006 \\
\hline & 2006 & & & SCJD & IPD_g & & & & & Wild type bank voles & IC & Nonno, 2006 \\
\hline & 2005 & & & & & & BSE & & & Macaque (Cynomolgus) & Oral & Lasmezas, 2005 \\
\hline & 2002 & & & SCJD & & & BSE & vCJD & & Tg (HuPrP129MM) mice & IC & Asante, 2002 \\
\hline & 2000 & & & & & & BSE & & & Sheep & Blood & Houston, 2000 \\
\hline & 1997 & & & SCJD & & iCJD & BSE & vCJD & & $\mathrm{Tg}$ (HuPrP129VV) mice & IC & Hill, 1997 \\
\hline & 1997 & & & SCJD & & iCJD & BSE & vCJD & & Wild type mice & IC & Hill, 1997 \\
\hline & 1997 & & & SCJD & & & & vCJD & & Wild type mice & IC & Bruce 1997 \\
\hline & 1996 & & & & & & BSE & & & Macaque (Cynomolgus) & IC & Lasmezas, 1996 \\
\hline \multirow{10}{*}{ vCJD (Will, 1996) } & 1996 & & & & & & BSE & & & Sheep & IC & Foster, 1996 \\
\hline & 1996 & & & & IPD_f & & & & & $\mathrm{Tg}$ (MHu2M) mice & IC & Telling, 1996 \\
\hline & 1995 & & & SCJD & & & BSE & & & $\operatorname{Tg}$ (HuPrP129VV) mice & IC & Collinge, 1995 \\
\hline & 1995 & & & & IPD_e & & & & & $\operatorname{Tg}(\mathrm{MHu} 2 \mathrm{M})$ mice & IC & Telling, 1995 \\
\hline & 1995 & & & & IPD_d & & & & & Tg (HuPrP129VV) mice & IC & Collinge, 1995 \\
\hline & 1995 & & & & IPD_c & & & & & Wild type NZW mice & IC & Tateishi, 1995 \\
\hline & 1994 & & Kuru & SCJD & IPD_b & iCJD & & & & Primates & IC & Brown, 1994 \\
\hline & 1993 & Scrapie & & & & & BSE & & & Marmosets & $\mathrm{IC}$ and IP & Baker, 1993 \\
\hline & 1990 & Scrapie & & & & & & & & Cattle & IC & Gibbs, 1990 \\
\hline & 1989 & & & SCJD & & & & & & Wild type mice & IC & Kitamoto, 1989 \\
\hline BSE (Wells, 1987) & 1988 & & & & & & BSE & & & Wild type mice & IC & Fraser, 1988 \\
\hline \multirow{2}{*}{$\begin{array}{c}\text { IPD (FFI) } \\
\text { (Lugaresi, 1986) }\end{array}$} & 1980 & Scrapie & Kuru & SCJD & & & & & & Monkey (Squirrel) & Oral & Gibbs, 1980 \\
\hline & 1975 & & & SCJD & & & & & & Guinea pig & $\mathrm{IC}$ and IP & Manuelidis, 1975 \\
\hline \multirow[t]{6}{*}{ iCJD (Duffy, 1974) } & 1973 & & & & IPD_a & & & & & Chimpanzees & IC & Roos, 1973 \\
\hline & 1972 & Scrapie & & & & & & & & Monkey (Cynomolgus) & IC & Gibbs, 1972 \\
\hline & 1968 & & & SCID & & & & & & Chimpanzees & IC & Gibbs, 1968 \\
\hline & 1968 & & Kuru & & & & & & & Monkey (Spider) & IC & Gajdusek, 1968 \\
\hline & 1966 & & Kuru & & & & & & & Chimpanzees & IC & Gajdusek, 1966; Beck, 1966 \\
\hline & 1961 & Scrapie & & & & & & & & Wild type mice & IC & Chandler, 1961 \\
\hline \multirow{2}{*}{ Kuru (Gajdusek, 1957) } & 1961 & Scrapie & & & & & & & & Goat & IC & Pattison, 1961 \\
\hline & 1939 & Scrapie & & & & & & & & Sheep & IC & Cuille and Chelle, 1936-1939 \\
\hline $\begin{array}{c}\text { IPD (GSS) (Gerstmann, } \\
\text { Straussler, Scheinker, } \\
\text { 1936) }\end{array}$ & $\begin{array}{l}1936 \\
(1928 \\
1913)\end{array}$ & & & & & & & & & & & \\
\hline $\begin{array}{c}\text { CJD (Creutzfeldt, } 1920 \text { \& } \\
\text { Jakob, 1921) }\end{array}$ & 1920 & & & & & & & & & & & \\
\hline Scrapie ( 1750) & $\sim 1750$ & & & & & & & & & & & \\
\hline
\end{tabular}

Fig. 1 History of the use of animal models of prion disease. The left column indicates when the diseases were first reported, starting with scrapie in the 18th century and CJD in 1920. The time line (second column) is not strictly chronological, but is aligned with the generation of relevant animal models. The subsequent columns, titled "inocula", indicate the different forms of prions that were transmitted. The column "recipient" indicates the species and, where appropriate, their genotypes. To the right, the transmission route and the reference. The inocula in the column IPD are complex and are according to the following key: $a$ CJD in patients with family history (specific mutation not known); $b$ E200K, D178N 129V, P102L, 5-OPRI, 7-OPRI, and 8-OPRI; $c$ D178N 129M and 24 basepair deletion mutation on the same PRNP allele; $d$ D178N 129M; $e$ E200K; $f$ D178N 129M; $g$ E200K, V210I; $h$ 6-OPRI; $i$ P102L, A117V, and E200K; $j$ P102L, A117V, and F198S; Tg (HuPrP-mut) mice recipients: *HuPrP-P102L, HuPrP-A117V, and HuPrP-E200K; abbreviations for routes of transmission: IC intracerebral, IP intraperitoneal

transmission of inherited prion disease (IPD) (V210I, E220K, A117V; P102L, and F198S) into bank voles is not dissimilar to that in humanised transgenic mice [128, 141]. Importantly, in bank voles, the neuropathological and biochemical strain properties are well preserved [128]. However, whilst these models show deposition of abundant abnormal prion protein in the brain [187], the neuropathological phenotypes and the biochemical characteristics of the modelled IPD do not correspond well to the human pathologies. 


\begin{tabular}{|c|c|c|c|c|c|c|c|c|c|c|c|c|c|c|c|}
\hline & 1 & 2 & 3 & 4 & 5 & 6 & 7 & 8 & 9 & 10 & 11 & 12 & 13 & 14 & 15 \\
\hline 2016 & KO & TgBVDel & TgBVSub & TgBVSub & TgBVSub & TgBVSub & TgBVSub & TgBVSub & TgBVSub & TgBVSub & TgBVSub & TgIntCross & TglntCross & & \\
\hline 2015 & $\mathrm{TgHu}$ & $\mathrm{TgHu}$ & $\mathrm{TgHu}$ & $\mathrm{TgHu}$ & $\mathrm{TgHu}$ & $\mathrm{TgHu}$ & TgHu & TgHu & TgMoSub & TgMoSub & TgMoSub & TgMoSub & TgMoSub & TgHuSub & $(4 x)$ \\
\hline 2014 & $\mathrm{TgHu}$ & $\mathrm{TgHu}$ & $\mathrm{TgHu}$ & $\mathrm{TgHu}$ & $\mathrm{TgHu}$ & TgMHDel & TgMHDel & & & & & & & & \\
\hline 2013 & $\mathrm{TgHu}$ & TgMoSub & TgHuSub & & & & & & & & & & & & \\
\hline 2012 & TgMHu2M & $(17 x)$ & $\operatorname{TgBV}(7 x)$ & & & & & & & & & & & & \\
\hline 2011 & $\mathrm{TgHu}$ & TgMoDel & TgMHuSub & & & & & & & & & & & & \\
\hline 2010 & TgMHu2M & TgMoDel & TgMoDel & TgMoDel & Tg-Prom & TgIntCross & & & & & & & & & \\
\hline 2009 & $\mathrm{TgHu}$ & $\mathrm{TgHu}$ & $\mathrm{KIHU}$ & $\mathrm{KIHu}$ & $\mathrm{KIHu}$ & $\mathrm{KIHu}$ & $\mathrm{KIHu}$ & TgMoSub & TgMoSub & TgHuSub & TgHuSub & TgHuSub & TgHuSub & & \\
\hline 2008 & KO & $\mathrm{TgHu}$ & TgMoSub & & & & & & & & & & & & \\
\hline 2007 & KiHulns & TgKIHu & TgKIHu & TgKIHu & & & & & & & & & & & \\
\hline 2006 & $\mathrm{TgHu}$ & $\mathrm{TgHu}$ & $\mathrm{TgHu}$ & $\mathrm{KIHu}$ & $\mathrm{KIHu}$ & $\mathrm{KIHu}$ & $\mathrm{KIHu}$ & $\mathrm{KIHu}$ & $\mathrm{KIHu}$ & TgKIHu & $\mathrm{TgKIHu}$ & & & & \\
\hline 2005 & $\mathrm{TgHu}$ & $\mathrm{TgHu}$ & TgMoDel & TgMoDel & Tg-Prom & TgMoSub & & & & & & & & & \\
\hline 2004 & Tg-Prom & TgMoDel & & & & & & & & & & & & & \\
\hline 2003 & TgMHu2M & PrPFc2 & PrPFc2 & PrPFc2 & & & & & & & & & & & \\
\hline 2002 & $\mathrm{TgHu}$ & $\mathrm{TgHu}$ & KIChM & TgMoO & TgMo & ConKo & ConKO & TgMoAlt & TgMoAlt & TgMoAlt & TgMoAlt & TgMoAlt & TgMoAlt & & \\
\hline 2001 & KO & KO & & & & & & & & & & & & & \\
\hline \multicolumn{16}{|l|}{2000} \\
\hline 1999 & TgMoSub & TgMoSub & & & & & & & & & & & & & \\
\hline 1998 & TgMoAlt & TgMoAlt & TgMoAlt & TgMoDel & TgMoDel & TgMoDel & TgMoDel & TgMoDel & TgMoDel & TgMolns & & & & & \\
\hline 1997 & TgHaSub & TgHaSub & TgHaSub & TgHaSub & TgMHuSub & TgMHuSub & & & & & & & & & \\
\hline 1996 & $\mathrm{KIHu}$ & $\mathrm{TgMoO}$ & TgMoO & TgMoSub & TgMoSub & TgMoSub & TgMoSub & TgMoAlt & TgMoAlt & TgMoDel & TgMoDel & TgMoDel & TgMoDel & TgHaSub & TgHaSub \\
\hline 1995 & KO & KO & $\mathrm{TgHu}$ & TgMoSub & TgMoSub & TgMoAlt & TgMoAlt & TgMoAlt & TgMHuSub & $\mathrm{TgHa}$ & $\mathrm{TgHa}$ & & & & \\
\hline 1994 & ко & $\mathrm{TgHu}$ & $\mathrm{TgHu}$ & TgMHu2M & TgMoO & TgMoO & TgMoSub & TgMoSub & & & & & & & \\
\hline 1993 & TgMHM2 & TgMHM2 & TgMHM2 & TgMHM2 & & & & & & & & & & & \\
\hline 1992 & KO & & & & & & & & & & & & & & \\
\hline \multicolumn{16}{|l|}{1991} \\
\hline 1990 & TgMoO & TgMoO & TgMoSub & $\mathrm{TgHa}$ & & & & & & & & & & & \\
\hline 1989 & $\mathrm{TgHa}$ & $\mathrm{TgHa}$ & $\mathrm{TgHa}$ & & & & & & & & & & & & \\
\hline \multirow[t]{13}{*}{1982} & \multicolumn{15}{|c|}{ First transgenic mouse model (not related to prion disease) } \\
\hline & $\mathrm{TgHa}$ & \multicolumn{4}{|c|}{ Tg mouse expressing hamster PrP } & TgMosub & \multicolumn{4}{|c|}{$\begin{array}{l}\text { Tg mouse with single amino acid substitution in } \\
\text { mouse PrP (to model IPD) }\end{array}$} & $\operatorname{TgBV}$ & \multirow{3}{*}{\multicolumn{4}{|c|}{$\begin{array}{l}\text { Tg mouse expressing bankvole PrP } \\
\text { Tg mouse with single amino acid substitution in } \\
\text { bankvole PrP (to model IPD) } \\
\text { Tg mouse with deletion in bankvole PrP (to model } \\
\text { IPD) }\end{array}$}} \\
\hline & TgMHM2 & \multicolumn{4}{|c|}{ Tg Mouse/Hamster chimera } & TgMolns & \multicolumn{4}{|c|}{ Tg mouse with insertions in mouse PrP } & TgBvSub & & & & \\
\hline & TgMHDel & \multicolumn{4}{|c|}{ Tg Mouse/Hamster chimera with deletions in PrP } & TgMoAlt & \multicolumn{4}{|c|}{$\begin{array}{l}\text { Tg mouse with mouse PrP various other } \\
\text { alterations }\end{array}$} & TgBVDel & & & & \\
\hline & TgHaSub & \multicolumn{4}{|c|}{$\begin{array}{l}\text { Tg mouse with single amino acid substitution in } \\
\text { hamster PrP (to model IPD) }\end{array}$} & Tg-Prom & \multicolumn{4}{|c|}{$\operatorname{Tg}$ mouse expressing $\operatorname{Pr} P$ under promoters } & & & & & \\
\hline & KO & \multicolumn{4}{|c|}{ Prnp knockout mouse } & PrPFc2 & \multicolumn{4}{|c|}{$\begin{array}{l}\text { Tg mouse with mouse PrP fused to human IgG1 Fc } \\
\text { tail }\end{array}$} & & & & & \\
\hline & ConKo & \multicolumn{4}{|c|}{$\mathrm{Tg}$ conditional Prnp knockout mouse } & TgIntCross & \multicolumn{4}{|c|}{$\begin{array}{l}\text { Tg mouse with altered mouse PrP intercrossed } \\
\text { with different mouse models }\end{array}$} & & & & & \\
\hline & TgMHu2M & \multicolumn{4}{|c|}{ Tg Mouse/Human chimera } & $\operatorname{TgHu}$ & \multicolumn{4}{|c|}{ Tg mouse expressing human PrP } & & & & & \\
\hline & KiChM & \multicolumn{4}{|c|}{ Knock in Mouse/Human chimera } & $\mathrm{KIHu}$ & Knock in mo & use expressir & g human PrP & & & & & & \\
\hline & TgMHuSub & $\begin{array}{l}\text { Tg Mouse/H } \\
\text { model IPD) }\end{array}$ & uman chimer & a with PrP alt & teration (to & TgKIHu & Tg and knoc & in mouse ex & pressing hum & an PrP & & & & & \\
\hline & TgMo & $\operatorname{Tg}$ mose exp & ressing mous & e PrP & & TgHuSub & $\begin{array}{l}\text { Tg mouse w } \\
\text { model IPD) }\end{array}$ & th single ami & no acid subtit & ution (to & & & & & \\
\hline & TgMoO & Tg mouse ov & erexpressing & mouse PrP & & KIHuIns & $\begin{array}{l}\text { Knock in mo } \\
\text { insertion }\end{array}$ & use expressir & human PrP w & & & & & & \\
\hline & TgMoDel & Tg mouse wi & th deletions i & $n$ mouse $\operatorname{Pr} P$ & & & & & & & & & & & \\
\hline
\end{tabular}

Fig. 2 Detailed overview of genetically modified models in prion research. 1982 denotes the year of the first report of the generation of a transgenic mouse. The first use of transgenic mice in prion research was in 1989. The legend explains the abbreviation used in the main

\section{Mouse models: a history of milestones in prion research}

The initial use of mouse models was, as with other animals, for the transmission and adaptation studies by serial propagation of sheep scrapie to wild-type mice (Fig. 1; Table 1), to understand the biology of the species barrier and of prion strains. Whilst initially done on inbred mice, this has significantly changed with the availability of transgenic models (Fig. 2; Supplementary Table 1). The first transgenic mice in prion research, published in 1989-several years after the creation of the first transgenic animal graph. Multiple fields indicate the generation of multiple mouse lines, sometimes published in a single article (see also supplementary table for further details)

in 1982 [134] —expressed hamster transgenes and were an important milestone towards the understanding of transmission barriers and strains [163], as they for the first time allowed to circumvent the species barrier and demonstrated the relevance of the amino-acid sequence of the Prnp gene for the susceptibility to prions strains. Expression of the murine equivalent of the human P102L mutation was the first significant attempt to model IPD associated with the Gerstmann-Sträussler-Scheinker (GSS) syndrome. Mice showed neurodegeneration, but no distinctive prion protein accumulation as seen in humans with GSS. GSS brain 


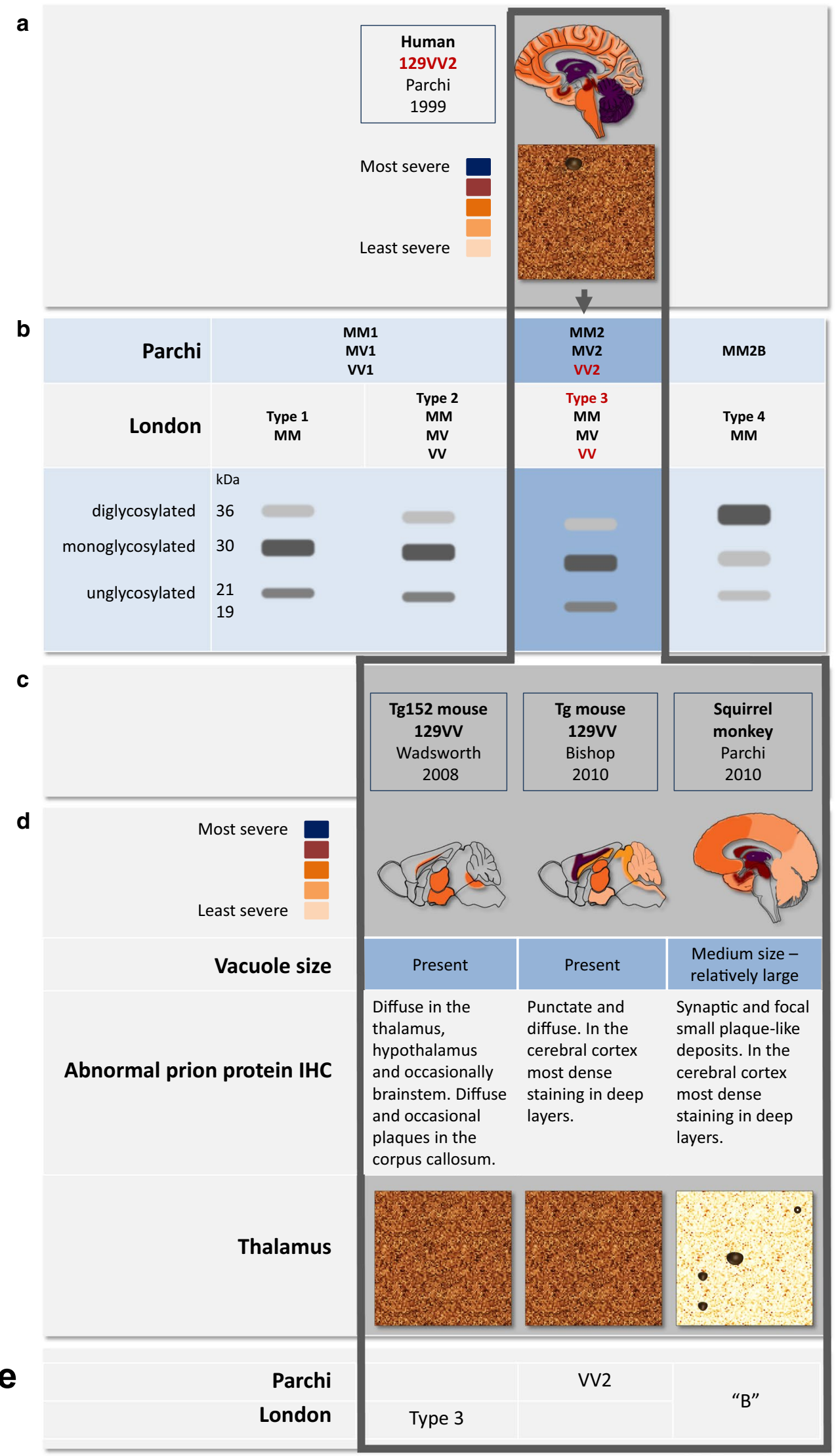


4Fig. 3 Comparison of neuropathology and molecular strain types between an SCJD patient with PRNP codon $129 \mathrm{VV}$ genotype and animal models. a Schematic representation of the severity of prion pathology and characteristic immunohistological pattern of synaptic and plaque-like abnormal prion protein deposits in the brain from sCJD patient with PRNP codon $129 \mathrm{VV}$ genotype. b Corresponding molecular strain is VV2 (Parchi classification) or type 3 (London classification). c Three animal models, two humanised mouse lines with $129 \mathrm{~V}$ genotype, and a squirrel monkey. d Schematic representation of the anatomical distribution of prion disease pathology, vacuolar size in the neuropil, and immunohistochemical pattern of abnormal prion protein deposits following disease development after intracerebral inoculation with the brain homogenate from the SCJD patient with $129 \mathrm{VV}$ genotype. e Corresponding molecular strain types in the animal models

extracts could be propagated within the same strain of mice [69], but not into inbred wild-type CD1 mice [70]. This model expressed human Prnp transgenes on a background of murine Prnp sequences, and this caused a significant interference of the transgenic prion protein with its endogenous homologue (Table 1). A further milestone in prion research followed in 1992 with the generation of the Prnp knock-out $\left(\right.$ Prnp $\left.^{0 / 0}\right)$ mouse [28] (Fig. 2), which not only demonstrated the requirement of the normal host prion protein to propagate prions [155], but also set the foundation to a nearly limitless numbers of models expressing a multitude of transgenes without interference of the endogenous protein. Weissmann, the creator of the mouse has befittingly phrased it "a mouse to remember" [190]. Economical animal maintenance and the continuous advances in gene editing and manipulation techniques have made mice a widely accepted and preferred model system, not only in prion research, but nearly universally in life sciences. New mouse models are continuously generated to address the biology of strains, function of PrP, transmission barrier, and with attempt to recapitulate human disease. The following paragraphs will outline the role of wild-type inbred strains of mice, the role of knock-out, transgenic and gene targeted mice in modelling human prion disease, and the function of PrP.

\section{Inbred strains of wild-type mice}

The commonest inbred strains used in prion research are C57Bl/6L, C57Bl/6N, C57BL/10, FVB, and 129/Ola, and nowadays, less commonly used strains are RIII, VM, NZW, and CD1. Initially, wild-type mice were used to transmit sheep scrapie and to generate and adapt scrapie strains for further propagation (Fig. 1). For example, the strain ME7 was the result of the transmission of natural scrapie of Suffolk sheep directly into mice. In contrast, other commonly used strains 22L, RML, and 79A, all distinct from ME7, share a common origin in that they were all derived from the Moredun Institute's sheep scrapie brain pool (reviewed in [168], and a detailed experimental characterisation is given in [97]). Likewise, many of these inbred mouse strains were also used, albeit with much less success, to transmit and propagate human prions of various aetiologies, i.e., sporadic, inherited, and acquired forms, including vCJD [26, 64, 83, 172]. The species barrier between humans and mice (also described as transmission barrier) results in low attack rates and markedly prolonged incubation periods. At the same time, the recognition of the existence of a species barrier was an important milestone as it eventually led to the generation of "humanised" transgenic mice and also to the transgenic mapping of the regions of the prion protein relevant for transmission barriers.

\section{PrP knock-out mice (PrP-null mouse, Prnp $^{0 / 0}$ ): a breakthrough in prion research to understand the role of $\operatorname{PrP}^{\mathrm{C}}$}

Since the publication of the first Prnp knock-out or Prnp null $\left(P_{r n p}{ }^{0 / 0}\right)$ mouse in 1992 [27, 28, 155], seven additional Prnp $^{0 / 0}$ models have been reported as of 2016 (Fig. 2; Supplementary Table 1). All these models lack significant regions of the Prnp open reading frame and they have in common that they do not express $\operatorname{PrP}^{\mathrm{C}}$. The two first published models were generated in Zürich (hence termed $\mathrm{ZH}$ or Zrch I Prnp ${ }^{0 / 0)}$ and in Edinburgh (Edbg Prnp ${ }^{0 / 0}$ [109]) and had only minor phenotypes [179] [Fig. 4(9)], whilst a model from Nagasaki, Japan (Ngsk Prnp ${ }^{0 / 0}$ ) developed ataxia, caused by a progressive loss of cerebellar Purkinje cells [156]. It was later found that this was caused by the deletion of a splice acceptor in intron 2 of the Prnp gene, which causes an intergenic splicing event and overproduction of the transcript of a gene named Doppel or $\mathrm{Dpl}$ [124]. Expressed under normal circumstances at very low levels, $\mathrm{Dpl}$ is massively upregulated in the brain of Ngsk Prnp ${ }^{0 / 0}$ mice due to the high activity of the Prnp promoter and results in the expression of Doppel protein in the CNS. A number of studies have then shown the role of Doppel protein in experimental neurodegeneration (for example, see [154]), and functionally intriguing links with truncated $\mathrm{PrP}^{\mathrm{C}}$, which causes a similar cerebellar phenotype, have been made (see below), but a direct relevance to human neurological diseases could never be established [117]. Other confounding factors were the embryonic stem cells and breeding schemes used for the generation of Prnp $^{0 / 0}$ mice. The most popular embryonic stem cell lines are derived from the mouse 1290la strain, whilst mouse lines are maintained in non-129 backgrounds. Using gene editing of C57BL/6J fertilised oocytes [130], a new Prnp ${ }^{0 / 0}$ mouse (termed Prnp ${ }^{\mathrm{ZH} 3 / \mathrm{ZH} 3}$ ) has been recently generated, which has eliminated all phenotypes previously reported, except chronic demyelination of peripheral nerves. Thus, the authors conclude that the demyelinating neuropathy is indeed the (only) effect of the Prnp loss of function [Fig. 4(8, 9)]. 


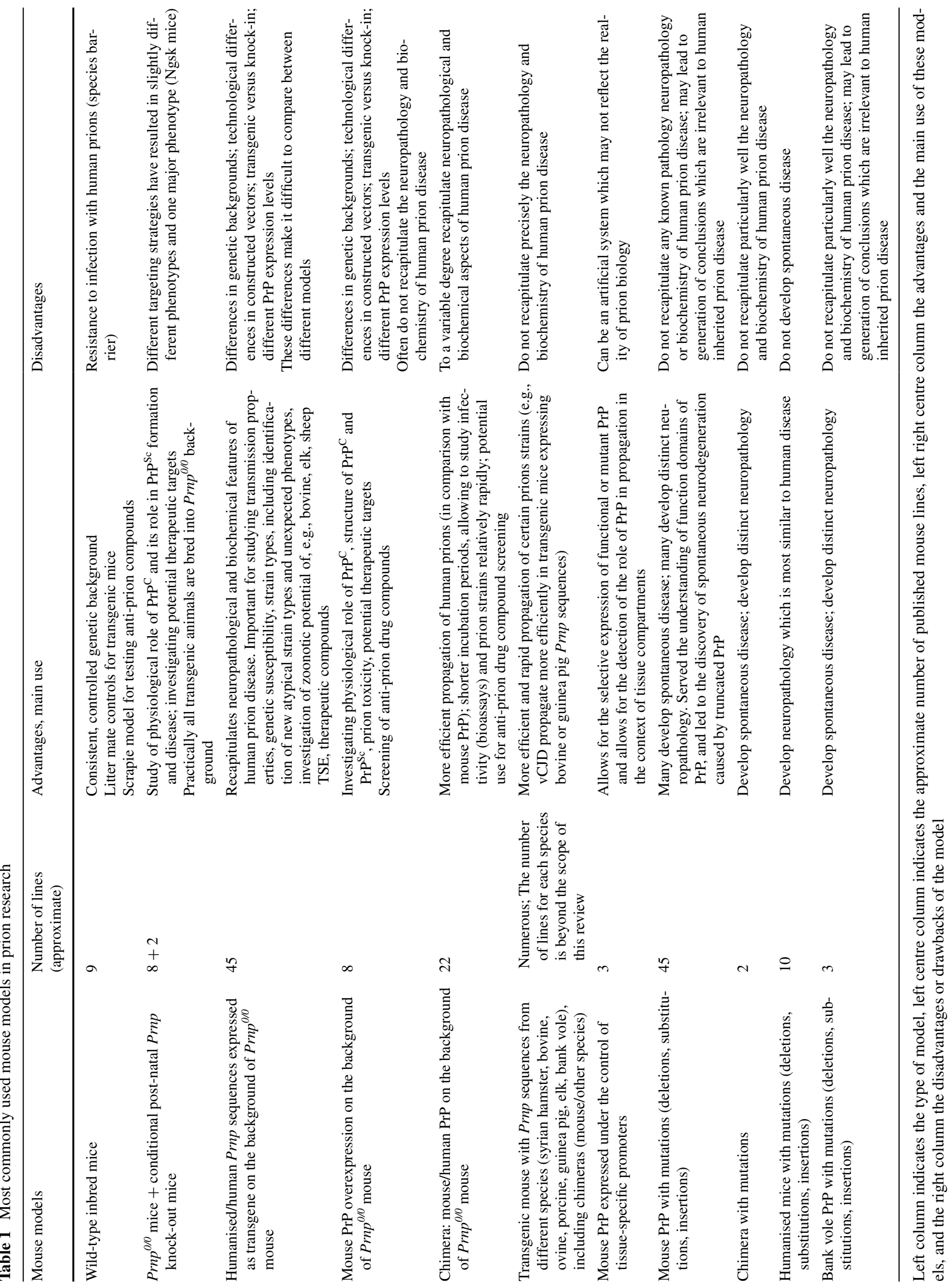




\section{Human PRNP transgenesis on the background of $P_{r n p}{ }^{0 / 0}$ mice: a leap forward to understand human prion disease}

The generation of $\operatorname{Prnp}^{0 / 0}$ mice was an essential tool to create transgenic mice lacking the endogenous murine $\operatorname{PrP}^{\mathrm{C}}$. Transmission of human prions into wild-type mice was fraught with significant transmission barriers and long incubation times [174], and this obstacle was effectively removed by intercrossing transgenic mice expressing fulllength human PrP or chimeric murine-human PrP (containing components of human and murine genome) with $\operatorname{Prnp}^{0 / 0}$ mice (Fig. 1). These models had comparatively short incubation periods with a high attack rate, they developed clinical phenotypes, and were suitable for the study of transmission barriers from other species and from distinct human prion isolates, which they often faithfully replicated neuropathologically and biochemically. As a consequence, these models have a significant potential to test therapeutic compounds developed in silico and in vitro. In fact, these features render these models superior to those of many major neurodegenerative diseases, such as Alzheimer's or Parkinson's diseases, where clinical-pathological correlation between the animal model and human disease often so far remain less compelling.

At present, at least 45 humanised mouse lines have been generated with combined transgenic and gene targeting approaches on the basis of Prnp ${ }^{0 / 0}$ mutants (Figs. 2, 3). The transgenic constructs not only carry the desired pathogenic mutations, but importantly the polymorphic genotypes at codon 129 (and more recently codon 219 and codon 127 $\mathrm{G}>\mathrm{V}$ modification [9]) of the PRNP gene. Over the years, the importance of a well-controlled genetic background has been increasingly recognised. Early studies often used mixed backgrounds (e.g., the $129 \mathrm{~V}$ line $(\mathrm{Tg} 152)$ or the 129M line (Tg35) were initially kept in a FVB/N, C57BL, and 129Sv background [6]), whilst later, these lines were maintained on a strictly FVB-congenic background [9]. The comparability between different mouse lines is then further confounded by the different PrP expression levels. For example, Tg650 mice (HuM129, sixfold PrP expression) [16] inoculated with vCJD prions develop neurological disease with a $100 \%$ attack rate, but $\mathrm{Tg} 35$ mice (HuM129, two-fold PrP expression) [6] and knock-in mice (replacing murine with single copy human $\operatorname{PrP}$ ) [18] only infrequently show neurological symptoms, whilst histological and biochemical examination clearly suggests subclinical disease. Likewise, transmission of SCJD, into the "knock-in" MM, MV, and VV models [19], does not result in clinical disease when inoculated with SCJD MM2 strains (Parchi classification [136], see also Fig. 3 for homologisation with the London classification). In contrast, Tg650 mice with much higher PrP levels develop clinical signs of prion disease with a mean incubation time of approximately 280 days [33]. Thus, for the purpose of disease modelling, for example, to assess drug effects on incubation time, PrP overexpression models have a clear advantage. This also is relevant for economical and practical reasons, such as cost of animal maintenance and the duration of typical research projects (e.g., life cycle of a grant or duration of a $\mathrm{PhD}$ ). From a practical aspect, doubling the expression levels can often be relatively easily achieved by breeding mice into homozygous status. On the other hand, a model system that produces strictly physiological PrP expression levels, such as the knock-in model, does have a role for the study of function of PrP, but the limited lifespan of a mouse may preclude the development of a phenotype during lifetime.

\section{Chimeric human/mouse models on the background of Prnp $^{0 / 0}$ mouse}

Since the generation of the first transgenic mouse line expressing chimeric mouse and human $\mathrm{PrP}$ was reported in 1994 [174], over 20 different chimeric human-mouse lines, designated MHu2M (25\% murine, 50\% human, and 25\% murine sequence) have been created. These lines differ in the amino-acid sequence of human PrP residues in the chimeric sequence, their PrP expression level, and incubation periods after inoculation with CJD prions [58]. These chimeric mice propagate human prions more "effectively", and therefore, new chimeric transgenic lines are generated to further reduce the incubation times. This is achieved by altering the sequence similarity of chimeric PrP, by reducing human, and by increasing murine sequences. The shorter incubation time of MHu2M models renders them particularly suitable for bioassays of human prion infectivity and strain properties, but the main limitation is that they poorly recapitulate other aspects of human prion disease.

\section{Conditional knock-out/knock-in models: the Cre-loxP system}

The use of the Cre/loxP recombination system enables "conditional" induction or inactivation of the gene of interest at a defined developmental time point, in a cell or tissue-specific manner, or both. The Cre-loxP-mediated knock-in gene replacement technique was first used in 1996 to generate humanised PrP mice [82] (Fig. 2; Supplementary Table 1) and has since been widely utilised. In addition to the generation of conditional knock-out [154] or knock-in mouse models [18], the Cre-lox system has been used in other modifications, for example, to generate mice with conditionally expressed soluble dimeric PrP to study the $\mathrm{PrP}^{\mathrm{C}}-\mathrm{PrP}^{\mathrm{Sc}}$ conversion process [121] [Fig. 4(11)]. A particularly successful model is the transgenic mouse expressing multiple copies of floxed ("flanked by LoxP 


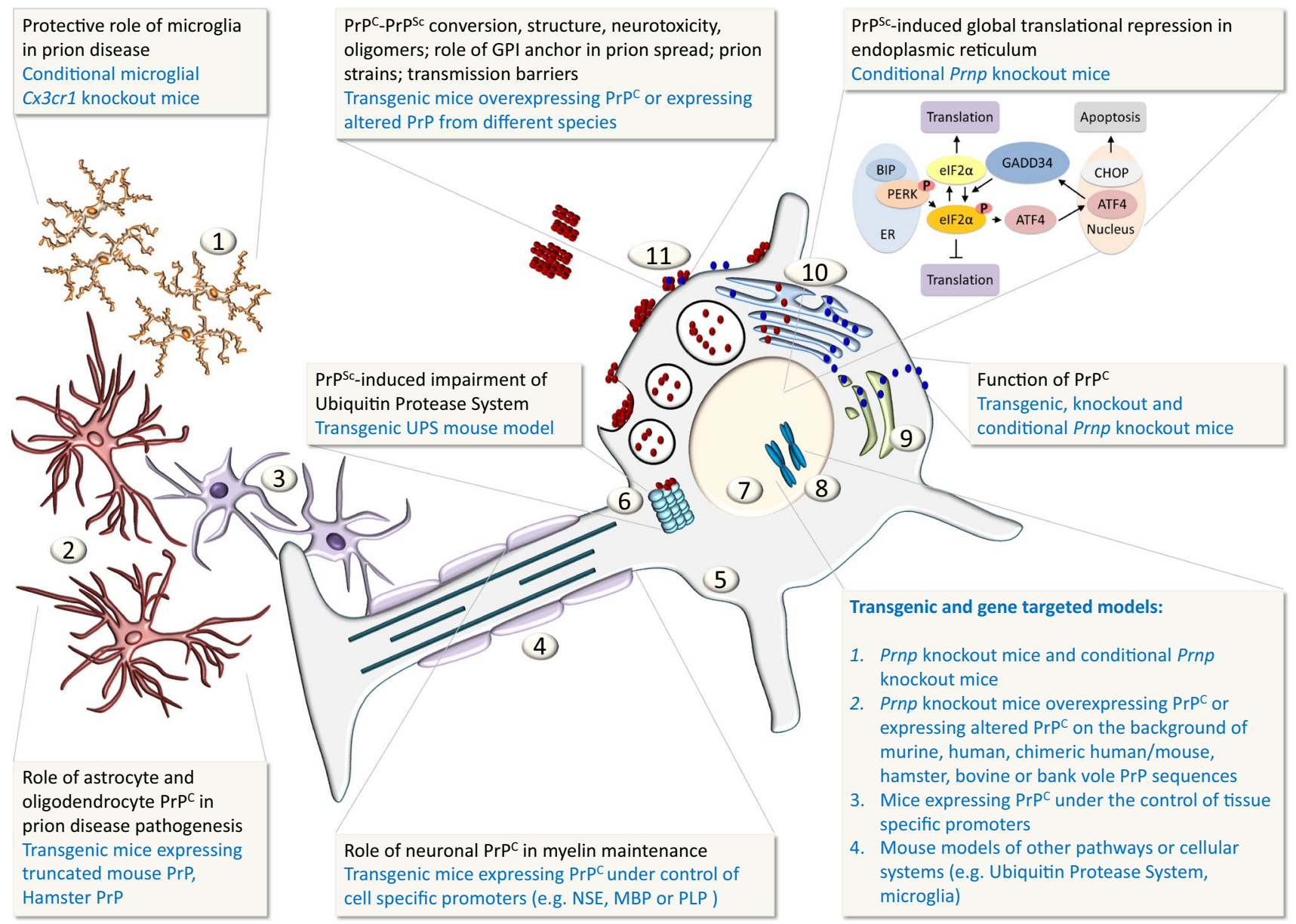

Fig. 4 Schematic representation of the cellular and sub-cellular compartments and how PrP function and disease mechanisms are investigated with animal models. Key: 1 microglia, 2 astrocytes, 3 oligodendrocytes, 4 myelinated axon, 5 neuronal cytoplasm, 6 ubiquitin

sites") Prnp (Tg37 and Tg46) [107, 108], where upon Cremediated recombination, the transgenically expressed $\operatorname{PrP}$ is excised at the age of $8-12$ weeks. This is achieved by intercrossing $\mathrm{Tg} 37$ or $\mathrm{Tg} 46$ lines with mice expressing Cre recombinase under the control of the neurofilament heavy chain promoter (NFH-Cre/Tg37 and NFH-Cre/Tg46). The fairly precise onset of Cre expression made this a highly successful model for studying the role of $\operatorname{PrP}^{\mathrm{C}}$ to understand the role of $\mathrm{PrP}^{\mathrm{Sc}}$ toxicity $[107,195]$ and to evaluate potential therapeutic compounds [125, 126, 195].

\section{Modelling the physiological and pathophysiological functions of PrP: expression of full length, partially deleted or tissue-specific PrP}

Following the generation of the $\operatorname{Prnp}^{0 / 0}$ mouse [28], a logical and scientifically important experiment was the reintroduction of PrP expression by transgenesis [53] (Fig. 2). The reintroduction of full-length PrP into Prnp ${ }^{0 / 0}$ mice protease system (UPS), 7 neuronal nucleus, 8 chromosomes, 9 Golgi complex, 10 Endoplasmic reticulum (ER), 11 blue globules represent native cellular prion protein $\operatorname{PrP}^{\mathrm{C}}$, red globules represent misfolded prion protein $\mathrm{PrP}^{\mathrm{Sc}}$

proved the restitution of the propagation of prion disease. Mice expressing full-length PrP were designated Tga20 (the letters "a" to "d" in the original publication indicate increasingly shortened Prnp open reading frames). Inoculation of Tga20 mice with RML prions resulted in very short (approximately 60 days) incubation times and a very short disease duration (of only one or two days as compared to a more protracted course of the disease in wild-type mice expressing two copies of Prnp). In contrast, heterozygous mice expressing only one allele of Prnp $\left(\operatorname{Prnp}^{+/ 0}\right)$ [53] had a significantly prolonged incubation times and a comparatively mild clinical course. Tga20 mice proved extremely popular for transmission experiments due to the very short incubation time for studies on neurotoxicity and prion spread within the brain or neural pathways into the brain $[22,23]$ and for studies of the kinetics of infectivity and prion protein accumulation $[157,158]$. Other models overexpressing PrP instead showed neurodegeneration and neuromuscular impairment [193]. 


\section{Mutants of PrP: deletions and point mutations}

In addition to the re-expression of full-length PrP, Fischer et al. [53] generated multiple amino-terminal deletion mutants of the Prnp open reading frame to understand the function of $\operatorname{PrP}$ and to determine the minimum requirement for prion replication. These in-frame deletions were of progressive length $(\Delta 32-93, \Delta 32-106, \Delta 32-121$, and $\Delta 32-134)$. This led to rather unexpected results, with a remarkable phenotype of progressive cerebellar degeneration in the $\Delta 32-121$ and $\Delta 32-134$ lines [165] [Fig. $4(9$, 11)]. It was speculated that this phenotype could have been caused by the formation of hetero-dimers with full-length PrP [15] and of the Doppel protein interacting with the truncated PrP. However, no human disease corresponding to this intriguing phenotype has been identified yet.

The aim of introducing point mutations into the Prnp open reading frame is to generate models of human IPD. An in-frame 144 basepair insertion into the open reading frame of the PRNP gene (6-octapeptide repeat insert, OPRI) in familial CJD [132] and the linkage of PrP missense variant, P102L, to the GSS syndrome were reported as early as 1989 [67]. A single amino-acid substitution in the mouse Prnp gene (101L, corresponding to the human 102L mutation) was the first model of an IPD (Fig. 2). These mice showed a spontaneous neurological disease, and neuropathological findings were spongiform degeneration and gliosis similar to human disease [70], but critically, no amyloid plaques were formed, in stark contrast to the characteristic neuropathological phenotype in humans. Since then, technological advances have made it possible to create increasingly sophisticated model systems, as for example, the introduction of double replacement gene targeting strategy to generate multiple mouse strains with subtle PrP alterations to understand molecular pathomechanisms of inherited prion diseases and the function of anchorless PrP [37].

\section{Ectopic and tissue-selective expression of PrP [Fig. 4(2,} $3,4)$ ]

Most models expressing PrP ectopically were generated to understand the function of $\operatorname{PrP}$ in a cellular or tissue context, i.e., to study in which cellular or organ system PrP can replicate and propagate infectivity, and eventually cause clinical or subclinical disease. Propagation of hamster prions selectively in astrocytes, but not in neurons was sufficient to render mice susceptible to prion disease [152] [Fig. 4(2)]. Transgenic mice expressing PrP on lymphoid cells (in Prnp $^{0 / 0}$ mice) led to the transmission of infectivity from the spleen into the brain that carried "sentinel" grafts derived from PrP-expressing neural stem cells [20]. More complex reconstitution experiments [85] in turn demonstrated that PrP expression on lymphoid cells is dispensable to propagate prions. Ectopic expression of PrP on oligodendrocytes [144] [Fig. 4(3)] did not help propagating infectivity, whilst expression of truncated forms of PrP (or of Doppel protein) selectively in oligodendrocytes showed myelinotoxicity [151], not a surprising finding, given that this protein also causes Purkinje cell death [154]. Selective expression of full-length PrP in the axon was shown to be required for myelin stability in the peripheral nervous system [24] [Fig. 4(4)].

\section{Transgenic mice expressing PrP sequences of non-human species}

A wealth of transgenic mouse lines has been created expressing PrP sequences of species other than human. The first transgenic mouse containing Syrian golden hamster PrP was reported in 1989 ([163]. Since then, mouse models expressing bovine, ovine, porcine, guinea pig, elk, and bank vole PrP sequences have been made-available for research of transmissible spongiform encephalopathies of both humans and animals. Likewise, increasing numbers of intercrossed lines have been generated to investigate the role of immune system and microglia [Fig. 4(1)] in prion disease pathogenesis $[167,196]$. Transgenic mouse lines of other model systems, particularly those related to immune system [24] and cellular processes [115], have shed light on important aspects of prion biology, but a comprehensive review of these models would be beyond the scope of this article.

\section{Nematodes and flies}

Unlike in research into other neurodegenerative diseases, invertebrate models, such as the nematode $C$. elegans and the fly Drosophila melanogaster, have so far been utilised very little in prion research. However, recent studies suggest that these models hold a potential for studying, among other aspects, prion neurotoxicity [178], infectivity [177], and testing anti-prion compounds of sporadic and inherited prion disease [56].

\section{Alternatives to animal models}

\section{Ex vivo models: organotypic slice cultures}

Ex vivo experiments are performed on tissue taken out from live organisms, and transferred into an artificial environment. Organotypic slice culture is a popular ex vivo model and the first such assay for studying prion amplification and titration was published in 2008 [51, 52]. Since then, this model system, in particular murine cerebellar organotypic 
cultured slices, has been used to study the physiological processes involved in prion formation, $\mathrm{PrP}^{\mathrm{C}}-\mathrm{PrP}^{\mathrm{Sc}}$ interactions, prion-induced neurotoxicity, and to test efficiency of novel therapeutics. Organotypic slice cultures hold potential to bridge the gap between often highly complex in vivo and simpler in vitro models. However, the advantage over in vivo mouse models which provide a much more complete picture on neuropathology, biochemistry, and behaviour has yet to be demonstrated. Even though initiatives to promote "3R" (refinement, reduction, and replacement of animal research) are supportive of such studies, the complexity of culture conditions to maintain brain tissue slices, lack of standardisation, and a potentially difficult readout may have prevented a wider adoption in neurodegeneration research.

\section{In vitro assays: a versatile, scalable, and reproducible alternative to animal models}

Cell-based in vitro models are instead widely used in the research on the cellular biology of prion propagation, alone or in combination with in vivo experiments. The greatest benefits of cell culture models, in comparison with animal studies and organotypic slices, are low costs and experimental simplicity, i.e., reproducibility, standardisation of culture conditions, and experimental readout. The successful infection of the mouse neuroblastoma cell line N2a with RML/Chandler inoculum was reported in 1987 [150], and since then, a wide range of sub-clones have been developed and characterised, of which the PK1 and R33 lines are arguably most commonly used. At least 15 different other animal-derived neuronal and non-neuronal cell lines, including sub-clones, have been developed over years, and each of which shows a distinct susceptibility to prion strains, which on the other hand prevents direct comparison between lines (for review, see [105, 180]). As always, the simplicity and versatility of these assays have a downside: whilst cell culture studies have contributed enormously to the understanding of the mechanisms governing prion biology, many of these findings are not directly relevant to human disease. It is indeed a disappointment that many of the anti-prion compounds, which have been effective in vitro, have failed in subsequent in vivo studies.

\section{Cell-free assays, purified recombinant prion proteins, and synthetic PrP fragments: from the principle of protein folding to the development of assays}

Since the first report of cell-free formation of proteaseresistant prion protein in 1994 [94], multiple tools and protocols have been developed to synthetise and purify recombinant mammalian PrP [102]. The most commonly used system for the synthesis of prion protein is Escherichia coli. Recombinant PrP of various species (human, mouse, bank vole, and Syrian hamster) has been generated, and many of these assays include deletions and truncations of PrP. Human recombinant PrP has been generated at full length [residues 23-231 (unglycolysated and lacking the GPI anchor)], and with various modifications, such as the expression of the globular domain only (residues 121-231 or 90-231), amino-terminal flexible tail residues (23-120) [98], and Y145Stop (23-144) [99]. The objective of generating synthetic PrP is to study the physiological function of PrP, its role in disease pathogenesis, and conformational properties. Whilst the formation of prions from recombinant PrP in a cell-free system has been demonstrated by some groups [102], a robust approach to reproducibly and systematically generate infectious prions from recombinant PrP in vitro has yet to be developed [161]. The systematic studies of conditions that lead to in vitro aggregation have also aided the development of cell-free assays for the detection of prions. It is beyond the scope of this review to discuss this in detail. Three major technologies, reviewed elsewhere in great detail $[10,162,192]$, are further discussed in the following.

\section{Computer modelling and bioinformatics approaches}

Advances in structural studies on molecules and computational modelling are the basis for the development of in silico molecular docking simulation methods, which allow analysing the interaction-binding modes and binding affinity-between various molecules. Thus, in silico computer simulation technique is emerging as a powerful tool for screening novel therapeutics, including anti-prion compounds $[63,133]$. It is predicted that the use of in silico virtual screening platforms for the identification of anti-prion compounds will continuously increase.

\section{Model systems in the context of specific biological questions}

In this section of the review article, the focus will be on models that could not be adequately discussed above. This is particularly relevant for crosscutting themes, and includes models which address specific biological questions or mechanisms.

\section{Identification of the transmissible nature of the disease-causing agent of scrapie and human prion diseases of different aetiologies (Fig. 1)}

The transmissible nature of human prion diseases was first demonstrated in non-human primates with the transmission of kuru [54] and sCJD in 1968 [57]. These transmission 
studies were encouraged by earlier studies of sheep scrapie. Whilst the transmissible and infectious nature of scrapie was long suspected, experimental studies were successful only in 1936 when brain and spinal cord extracts from diseased sheep were transmitted into sheep or goat and the recipients developed scrapie after a 2 year incubation period, confirming its transmissible nature [48, 49]. These experiments were successfully reproduced a few decades later by Pattison [138]. Following the characterisation of the transmission of kuru, it became increasingly apparent that the agent, previously thought to be a slow virus, harboured rather unusual biological properties. These studies were carried out in primates $[13,54,57]$ and led to the proposition of the protein-only hypothesis [61] with its subsequent experimental verification in hamsters and mice [21, 146, 147]. In comparison, the proof that vCJD is caused by BSE was established significantly faster, due to the availability of humanised transgenic mice [26, 64] also providing a significant additional insight into the pathogenesis of vCJD [45]. The transmission properties of prions derived from various inherited prion diseases have been extensively studied in animal models, such as primates, inbred wild-type mouse strains, transgenic mice, and bank voles (Fig. 1) [4, 25, 44, 110, 118, 128, 140, 141, 172, 173, 175]. Prion transmission into knock-in humanised mice expressing PrP at various levels and carrying M129 or V129 alleles has been important in deciphering the basis for two distinct neuropathological and biochemical patterns of dural graft-related iCJD. These studies demonstrate that the observed neuropathological differences in these patients are best explained by their infection with distinct sCJD prion strains, and suggest that the human cadaveric dural graft pools may have been contaminated with prions from more than one donor [89]. More recently, the transmission of a newly identified form, variably protease-sensitive prionopathy (VPSPr), has also been confirmed in humanised mouse models $[50,129]$. The observed extremely low transmission levels in one of the studies suggest that VPSPr has transmission properties distinct from other prion diseases, such as SCJD and vCJD [50].

\section{Models to understand species barriers}

First evidence of an interspecies transmission barrier of prions and an experimental approach how to overcome it was demonstrated in 1961 when mice developed prion disease following inoculation with brain extracts from goats that had been inoculated with isolates from scrapie sick Suffolk sheep [32]. Following the primary transmission, which showed a species barrier, subsequent passages were $100 \%$ effective, with mouse strain specific incubation times [31]. A transmission barrier is defined as an incomplete penetrance of the disease with prolonged incubation periods compared to the host [137]. The species (or transmission) barrier has been extensively modelled in transgenic humanised mice expressing either full-length human or chimeric human and mouse PrP genes (Figs. 1, 2). In vivo and in vitro studies have revealed that both the species-specific primary sequence homology of $\operatorname{PrP}$ (that is, differences in amino-acid sequence between host $\operatorname{PrP}^{\mathrm{C}}$ and donor $\operatorname{PrP}^{\mathrm{Sc}}$ ) and prion strain conformation are the major factors determining the species barrier [41]. To circumvent the species barrier and thus facilitate transmission of CJD, a number of different lines of transgenic mice have been produced. Mouse models expressing chimeric mouse-human prion protein transgenes have been particularly important in demonstrating the significance of the primary sequence of PrP to abnormal prion protein cross-seeding efficacy from different species. The relevance of sequence homology has subsequently also been shown in in vitro conversion assays [17, 95] and in experiments with scrapie-infected neuroblastoma cell lines [145]. The significance of prion strain conformation for interspecies transmission barrier as opposed to merely PrP sequence homology is highlighted in studies on yeast prions [171, 176], in study with recombinant PrP from various species [76] and more recently in studies with bank voles [128]. Substitution of a single amino acid in a critical region can be sufficient to change the species specificity and thus remove a species barrier as shown in studies with purified recombinant PrP23-144 of human, mouse, and Syrian hamster, where assets at position 138 and 139 are determinants of species-dependent seeding specificity [181].

Transgenic mice overexpressing human $\operatorname{PrP}$ on the background of $P r n p^{0 / 0}$ mice have been widely used to modulate and, when necessary, eliminate the species barrier when transmitting common animal prion diseases, such as BSE, chronic wasting disease, (CWD) and scrapie. Whilst the zoonotic potential of BSE has been unequivocally confirmed through transmission into transgenic mice expressing bovine, chimeric or human sequences [6, 64, 164], a number of studies using various different mouse models overexpressing human PrP on the background of $\operatorname{Prnp}^{0 / 0}$ mice have demonstrated lack of such a potential for scrapie and CWD [96, 149, 159, 170]. More recent studies, however, utilizing PMCA in the same model (Tg440, overexpressing human $\operatorname{PrP} 129 \mathrm{M}$ ) show that cervid $\operatorname{PrP}^{\mathrm{Sc}}$ can, in fact, induce the conversion of human $\operatorname{PrP}^{\mathrm{C}}$ after the cervid $\mathrm{PrP}^{\mathrm{Sc}}$ strain has been adapted by successive passages in vitro or in vivo [11]. In addition, the zoonotic potential of scrapie has recently been demonstrated in cynomolgus macaques following a 10-year incubation period [46] and in mice overexpressing human $\operatorname{PrP}[\operatorname{Tg} 340$ (M129) and Tg361 (V129)] [30]. Whilst in mice, the efficiency of transmission of the primary passage was low, subsequent serial passages of different scrapie isolates resulted in higher 
attack rates and the propagation of prions which are phenotypically indistinguishable to SCJD strains (MM1 and VV2, respectively; Parchi classification, see also Fig. 3 for homologisation with the London classification) [30]. This strain shift of the BSE/vCJD strain towards a human phenotype (i.e., sCJD) inevitably has potential public health implications [7], in that exogenous (i.e., potentially zoonotic) prions adapt towards, and may become indistinguishable from human strains, as shown also for CWD [11] or scrapie [30].

\section{Prion strains}

An enormous advantage of modelling prion diseases over any other neurodegenerative disorder is the ease of inducing it through infection with prions, most commonly by intracerebral inoculation. Prions differ in their conformational states, which forms the basis of the general model of distinct prion strains [41]. In addition to well-characterised strains of sporadic, acquired and inherited human prion diseases, those derived from hamster prions ( $\mathrm{Sc} 237$ and $263 \mathrm{~K}$ ), mouse-adapted BSE prions (301C and 301V), mouse-adapted scrapie prions, (RML, ME7, 139A, and 79A), and anchorless prions derived from $\mathrm{Tg} 44$ mice (22L) have been extensively used to study human prion disease. A widely used animal strain into the research of both human and animal prion diseases is a mouse-adapted sheep scrapie isolate. It is derived from the prion strain RML, which was first described in 1961 by Chandler, and therefore, sometimes is also referred to as Chandler strain [32].

Distinct human prion strains, such as SCJD, vCJD, kuru, iCJD, VPSPr and sporadic Fatal Insomnia, not only differ in their biochemical and neuropathological patterns, but also have characteristic transmission and propagation properties which have been extensively studied in transgenic humanised mouse models [3, 18, $19,90,111,122,129,183,186]$. The knowledge gained through these studies is important particularly from a public health point of view, as this can help identifying and characterising the origins of any new atypical strains. For example, transgenic mouse studies have shown that V2 $\mathrm{PrP}^{\mathrm{Sc}}$ infection of a mouse with $129 \mathrm{MM}$ genotype (strain classification according to the Parchi classification [136], see also Fig. 3 for homologisation with the London classification) generates an unusual $\mathrm{PrP}^{\mathrm{Sc}}$ with altered conformational properties, which retains the "memory" of $\mathrm{V} 2 \mathrm{PrP}^{\mathrm{Sc}}$ and re-emerges and replicates rapidly when transmitted to a mouse with a $129 \mathrm{VV}$ genotype. Such so-called trace-back studies are thought to be a reliable means for identifying the origin of prion strains [93]. Furthermore, based on the similarities between neuropathological and biochemical features of $129 \mathrm{MM}$ mice infected with the $\mathrm{V} 2 \mathrm{PrP}^{\mathrm{Sc}}$ strain and those seen in one type of dural graft iCJD, it has been suggested that the combination of PRNP 129MM genotype, kuru plaques, and a specific $\operatorname{PrP}^{\mathrm{Sc}}$ biochemical pattern may indicate an acquired aetiology of CJD [91-93].

\section{Genetic susceptibility: models of $P R N P$ gene polymorphisms and mutations}

The human PRNP gene encodes methionine (M) or valine $(\mathrm{V})$ at residue 129 , which has a strong effect on the susceptibility to human prion diseases [119, 123]. In northern Europe $38 \%$ of the population are MM, $51 \% \mathrm{MV}$ and $11 \%$ are VV. Sporadic CJD occurs most frequently in MM homozygous individuals and it is also relevant in the acquired forms of CJD, most strikingly in VCJD, where most clinical cases studied so far have been homozygous for methionine at codon 129 of PRNP. A polymorphism at codon $127(\mathrm{G} 127 \mathrm{~V})$ of $P R N P$ has recently been determined as a resistance factor against the kuru epidemic and this observation also dismissed speculations of possible pathogenic mutation that could have triggered the kuru outbreak [120]. In fact, it demonstrates that the polymorphisms at codon 127 and 129 of $P R N P$ are a population genetic response to an epidemic of prion disease and can be regarded as a powerful episode of recent selection in humans [120]. Another polymorphism, occurring in Asian populations, with an allele frequency of $6 \%$, is E219K, which has been reported to have a protective effect for SCJD and it influences the clinical-pathological features of GSS with P102L mutation [66].

The importance of the polymorphisms as a disease modifier is also highlighted in the context of pathogenic mutations of the PRNP gene, associated with IPD. More than 40 different mutations have been described and comprise changes of the number of octapeptide repeats in the N-terminal domain, PrP missense mutations causing an aminoacid variant in most cases or rarely a premature stop codon [14]. The most common mutations are octapeptide repeat insertions and the point mutations P102L, D178N, E200K, and V210I [14], respectively. IPD comprises a range of heterogenous clinical presentations and neuropathological patterns and represent approximately $15 \%$ of all prion diseases (for a summary of genotype-phenotype correlations, see [116]).

To understand the profound influence of common polymorphisms at residue $129[6,7,183]$, the rare 
polymorphism at residue 127 [9] and residue 219 [66] of the $P R N P$ gene in susceptibility to acquired, sporadic and some inherited prion diseases and association of different polymorphisms with certain prion strains, transgenic, and knock-in humanised mouse models have been of particular importance. A comprehensive list of mouse models of human polymorphisms is given in Supplementary Tables 1 and 2. Studies in mice expressing different combinations of $129 \mathrm{M}$ and $129 \mathrm{~V}$ have been fundamental to understand the contribution of this polymorphism to susceptibility of different human prion strains. These models suggest that individuals with PRNP 129MV may be more susceptible to infection with vCJD prions than to cattle BSE prions and may present with a neuropathological phenotype distinct from vCJD [7]. BSE transmission into PrP 129VV mice caused clinical disease with no detectable $\operatorname{PrP}^{\mathrm{Sc}}$, a phenotype that is also seen in clinically affected BSE-challenged wild-type mice. Thus, BSE and vCJD prion infection in transgenic mice can result in the propagation of distinct molecular and neuropathological phenotypes dependent on host $\operatorname{PrP}$ residue 129 [7]. These data predict a critical role for PRNP codon 129 in governing the thermodynamic permissibility of human $\mathrm{PrP}^{\mathrm{Sc}}$ conformation that can be interpreted within a conformational selection model of prion transmission barriers [183].

The recent mouse model for the protective effects of the V127 allele (which is seen only in combination with the M129 PRNP allele) [9] elegantly confirms that mice expressing the PrP V127 variant (on one allele, e.g., V127M129; G127M129) are unable to propagate kuru and sCJD prions, but they do propagate vCJD prions. Instead, mice homozygous for human PrP V127 (i.e., V127M129; V127M129) amazingly show a complete resistance to kuru, vCJD, sCJD, GH-iCJD, and DG-iCJD strains. It is obvious that there is a significant potential for further structural studies and eventually to develop effective drug interfering with prion replication.

The E219K polymorphism, prevalent in Asian populations and associated with a partial resistance to SCJD, has been replicated in a knock-in mouse model, which demonstrated that the PrP $219 \mathrm{~K}$ molecule is readily converted to $\operatorname{PrP}^{\mathrm{Sc}}$ after challenge with $\mathrm{vCJD}$ and that the conversion occurs even more effectively than in the $219 \mathrm{E}$ molecule. However, heterozygous 219E/K mice ("mismatch") showed the least effective conversion, indicating so-called "heterozygous inhibition" [66]. With mismatching alleles, attack rates were much lower and incubation periods longer. Based on these findings, the "conformational selection" hypothesis has been proposed, where the transmission of infectious prions with shorter incubations periods is facilitated if the host prion protein can readily adopt the preferred conformation associated with the strain of the infected prion [40, 41, 182].
Models of PRNP gene mutations (Fig. 5): more promises than they can deliver?

The first genetic confirmation of the PRNP P102L mutation causing GSS in 1989 in two pedigrees [67] prompted the generation of mouse models for further study of the disease mechanism, understanding of phenotypic variability, and transmission properties $[68,70]$. Since then, P102L models have been refined $[4,185]$ although have not always held the promise of full understanding of all aspects of the disease [5] with some results contradicting earlier studies [4]. A number of common point mutations (P102L [4], A117V [8], D178N, E200K [4, 73], as well as octapeptide insertion mutations [74], and mutations associated with formation of anchorless PrP [37]) have been modelled in mice. Whilst the most common approach has been the expression of a transgene on a $\operatorname{Prnp}^{0 / 0}$ background, also mice expressing murine, chimeric human/mouse, human, Syrian hamster, bovine, and more recently bank vole PrP sequences have been used. A comprehensive overview of available models expressing pathogenic PrP mutations is given in Fig. 5. With the development of different models, it has emerged that reproducing aspects of human IPD is far more challenging and unsatisfactory than modelling sporadic and acquired human prion diseases. The IPD models have one or more shortcomings: some either do not develop spontaneous disease at all, the disease is not fatal, the attack rates and transmission properties on further passages are variable, or the neuropathology and strain properties do not correspond to human equivalent. For example, the most recently published transgenic mice, generated with an attempt to reproduce human genetic prion disease express bank vole PrP containing corresponding D178N, E200K, and anchorless PrP mutations [187]. Although these mice develop transmissible, highly penetrant spontaneous disease with a neuropathological phenotype (vacuolar degeneration and abnormal PrP immunohistochemically detected deposits) distinct for each mutation, neither anatomical distribution nor neuropathological and biochemical findings correlate well with the human phenotype.

A range of mutant human PrP species (E220K, P102L, A117V, OPRI, D178N 129M, D178N 129V, F198S, and Y163X) has been transmitted into primates, bank voles, and transgenic mice expressing murine, human, or bank vole PrP. Except the truncating Y163X mutation, all other mutant prions are transmissible, but the resulting pathological phenotype does not correspond well to human disease. This discrepancy has recently been reported and discussed in a P102L transgenic mouse model. Contrary to conclusions from the previous studies, $102 \mathrm{~L}$ mutant prions are transmissible to transgenic mice expressing human PrP carrying the same mutation, but do not infect wild-type mice or mice expressing wild-type human $\operatorname{PrP}$ on background of $\operatorname{Prnp}^{0 / 0}$ [5]. 


\begin{tabular}{|c|c|c|c|c|c|}
\hline & Syrian hamster & \multicolumn{2}{|c|}{$\begin{array}{l}\text { TgSHaPrP(A117V)H (Hegde, 1999) } \\
\text { TgSHaPrP(A117V)L (Hegde, 1999) }\end{array}$} & $\begin{array}{r}\text { SHaPrPC(T183A) } \\
\text { (Dearmond, 1997) }\end{array}$ & \multirow[b]{2}{*}{$\begin{array}{l}\operatorname{Tg}(B V P r P, I 109, \Delta G P I) \\
\quad(\text { Watts, 2016) }\end{array}$} \\
\hline & \multicolumn{3}{|c|}{ 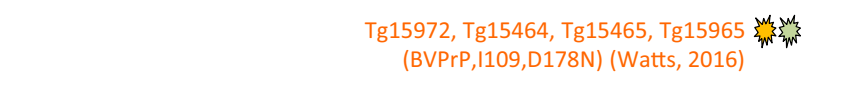 } & \\
\hline & Mouse & $\begin{array}{l}\text { PG14 (Mo-3F4) }{ }^{\sum_{3}} i_{w / 3} \\
\text { (Chiesa, 1998) }\end{array}$ & 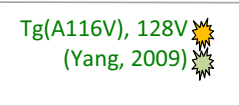 & 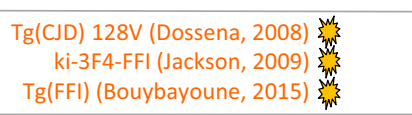 & 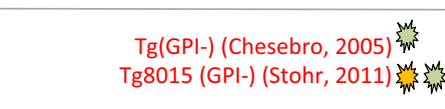 \\
\hline \multicolumn{3}{|c|}{$\begin{array}{l}\text { Human/Mouse } \\
\text { chimera }\end{array}$} & \multicolumn{2}{|r|}{$\begin{array}{l}\text { MHu2MPrP (D178N) } \\
\text { (Dearmond, 1997) }\end{array}$} & \\
\hline \multirow{2}{*}{\multicolumn{2}{|c|}{ Human }} & \multicolumn{2}{|r|}{$\begin{array}{l}\text { HuPrP117V,129V } \sum_{m w_{3}^{m}}^{m_{3}} \\
\text { (Asante, 2013) }\end{array}$} & \multicolumn{2}{|c|}{ 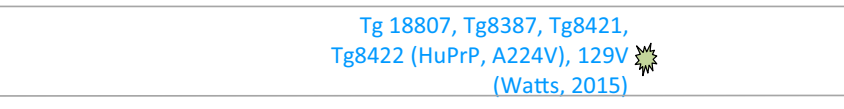 } \\
\hline & & 9-OPRI & $\underset{1}{A 117 V}$ & D178N $\left.\right|_{\mid}$T183A & $\underset{1}{A 224 V}$ Nonsense \\
\hline & & \multicolumn{2}{|r|}{$\begin{array}{c}\text { I } \\
\text { P102L }\end{array}$} & \multicolumn{2}{|r|}{ E200K } \\
\hline \multicolumn{2}{|r|}{ Human } & \multicolumn{3}{|c|}{$\begin{array}{l}\text { Tg27 and Tg33 HuPrP102L,129M } \\
\text { (Asante, 2009) }{ }^{\frac{\mathrm{m}_{3}}{\mathrm{~m}_{3}}}\end{array}$} & $\begin{array}{l}\text { Tg23 and Tg49 HuPrP200K,129M } \\
\text { (Asante, 2009) }{ }^{\frac{\mathrm{m}_{3}}{m_{w}}}\end{array}$ \\
\hline \multicolumn{2}{|r|}{$\begin{array}{l}\text { Human/Mouse } \\
\text { chimera }\end{array}$} & \multicolumn{3}{|c|}{ 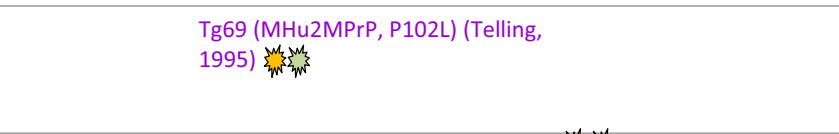 } & $\begin{array}{l}\text { (TgMHu2M)E199KPrP } \sum_{\sum_{w}}^{m_{3}} \sum_{m / 3}^{m_{w}} \\
\text { (Friedman-Levi, 2011) } \\
\text { MHu2MPrP(E200K) } \\
\text { (Dearmond, 1997) }\end{array}$ \\
\hline \multicolumn{5}{|c|}{ 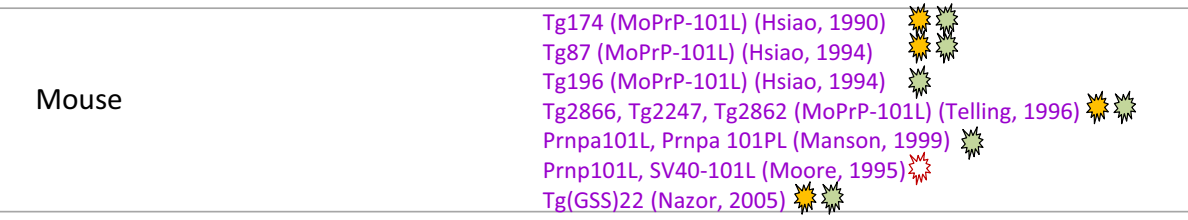 } & 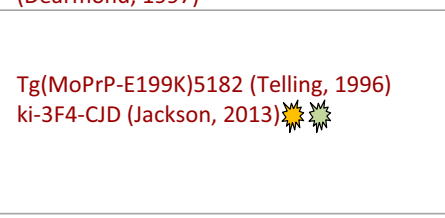 \\
\hline \multicolumn{2}{|r|}{ Bank vole } & & & & 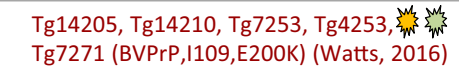 \\
\hline \multicolumn{2}{|r|}{ Cattle } & \multicolumn{3}{|c|}{ 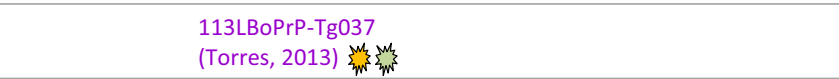 } & \\
\hline$\sum_{i_{w}}^{\sum_{m_{3}}^{m_{3}}}$ & \multicolumn{5}{|c|}{$\begin{array}{l}\text { Develop spontaneous disease } \\
\text { Distinct neuropathological changes following either spontaneous disease development or disease development after } \\
\text { inoculation with prions } \\
\text { Clinical and neuropathological aspects not assessed in the original study }\end{array}$} \\
\hline
\end{tabular}

Fig. 5 Transgenic mouse models of inherited prion disease. The open reading frame of the PRNP gene is represented in the centre, and the mutations that have been modelled in transgenic animals are shown above and below. On the left, the species PrP sequence of the transgene is shown, i.e., hamster, bank vole, mouse, and bovine sequences as well as chimeric constructs, such as human/mouse. The amber symbols next to the mutant indicate that the model developed a spontaneous disease and the green symbol indicates that there was a distinct neuropathological phenotype either spontaneously or following inoculation with prions. In one study, the clinical and neuropathological aspects were not assessed (open symbol). The mouse lines with no symbol did not develop spontaneous disease and did not show distinct neuropathology Blue or red letters are simply for orientation, to align with the point mutation shown in the centre
PrP point mutations directly influence $\mathrm{PrP}^{\mathrm{Sc}}$ assembly and PrP primary structure significantly influences the phenotype of inherited prion disease. For example, a kindred with substitution at residue 211 (E211D) and individuals with an E211Q mutation, respectively, are reported to have remarkably distinct clinical phenotypes, neuropathology, and biochemical alterations [139]. The E211D mutation was associated with a GSS phenotype clinically and pathologically, whilst the E211Q mutation had a short disease duration and no amyloid plaques. Such strong influence of a single amino-acid substitution on the phenotype has also been confirmed in vitro and in vivo [139] and in vivo [73]. In keeping, phenotypical variations have long been known in families with pathogenic mutations. One explanation is the spectrum of involvement of protease-resistant wild-type PrP, as demonstrated in P102L IPD [185]. This study showed that in patients with P102L mutations, a substantial proportion of abnormal PrP is derived from the wild-type allele. 
Models of the formation, spread, toxicity, different strains of the abnormal prion protein, and cellular pathways

\section{Bioassays: detection and measurement of infectivity titres}

A robust, sensitive, and specific bioassay to detect prion infectivity is undoubtedly highly desirable for clinical diagnostics, epidemiological studies, and laboratory experimental assays. For clinical diagnostic purposes, a bioassay would have to be sensitive, specific, and should be achievable in a comparatively short turnaround time. Therefore, the transmission into animals sensitive for human prion disease is not an option due to the long incubation times, comparatively high costs and ethical reasons. In addition, clinical studies would require validation and suitability of the assay for an accredited environment. Therefore, cell-free assays have the greatest potential for clinical purposes. The two most widely used cell-free assays are Protein Misfolding Cyclic Amplification (PMCA) [34] and Real-Time Quaking-Induced Conversion (RT-QuIC) [113]. PMCA uses $\operatorname{PrP}^{\mathrm{C}}$ for the amplification of $\operatorname{PrP}^{\mathrm{Sc}}$ through repeated series of incubation and sonification. RT-QuIC uses automated quaking or shaking for the amplification of $\mathrm{PrP}^{\mathrm{Sc}}$ from recombinant $\mathrm{PrP}^{\mathrm{C}}$. Both cell-free-based assays detect $\mathrm{PrP}^{\mathrm{Sc}}$ with remarkably high sensitivity. The limitations of PMCA are the risk of cross contamination and the generation of de novo $\operatorname{PrP}^{\mathrm{Sc}}$ by offtarget amplification. RT-QuIC is limited by the readout and a non-infective end product, which makes it unsuitable, for example, to study effectiveness of decontamination of anti-prion compounds. A blood based assay, developed for the detection of vCJD in blood, and also of early stages of preclinical disease (Direct Detection Assay, DDA) [160] utilises a solid-state binding matrix to capture and concentrate $\mathrm{PrP}^{\mathrm{Sc}}$, which is then detected immunologically. It is suitable for high-throughput screening in the surveillance of an atrisk population [72] and for the detection of abnormal $\operatorname{PrP}$ conformers in animal models (CD1 mice, $\mathrm{PrP}^{\mathrm{C}}$ overexpressing mice (Tga20), and Syrian hamsters) [160]. Scrapie cellbased assays (SSCA), based on a cell line derived from N2a cells that are highly susceptible to RML prions, have been in development over several decades [88], and with standardised methodology, they are suitable for automation and high throughput. Their refinement makes it possible to achieve high-throughput isolation of prions even to exceptionally high levels of purity with retained biological and biochemical prion strain properties [192].

Cell-based assays, in combination with animal studies, have been instrumental in understanding the dynamics of prion titres and the accommodation of toxic species in the progression of prion disease and for detailed correlation between neuropathological changes and prion titre [157, 158]. Instead, classical transmission studies by serial dilution of an inoculum and subsequent transmission into large cohorts of animals, popular in the early times of prion research, and gold standard to determine titres in brains or brain regions [22] are becoming increasingly obsolete.

\section{Formation of $\operatorname{PrP}^{\mathrm{Sc}}$ and toxic oligomers in vivo}

Conversion of $\operatorname{PrP}^{\mathrm{C}}$ into $\mathrm{PrP}^{\mathrm{Sc}}$ is a post-translational process, which occurs when $\operatorname{PrP}^{\mathrm{C}}$ reaches the extracellular domain. $\operatorname{PrP}^{\mathrm{C}}$ and $\operatorname{PrP}^{\mathrm{Sc}}$ have identical amino-acid sequences but differ in their secondary and tertiary structures. $\operatorname{PrP}^{\mathrm{Sc}}$ forms $\beta$-sheet-rich aggregates, which range from small, soluble oligomers to large insoluble fibrillary structures. The formation of $\operatorname{PrP}^{\mathrm{Sc}}$ and the development of neurodegenerative changes require $\operatorname{PrP}^{\mathrm{C}}$ as a substrate [22] Prion propagation in the brain involves two phases [157]. In the first phase, prions propagate exponentially andare not rate limited by the concentration of $\operatorname{PrP}^{\mathrm{C}}$. They rapidly rise and reach a maximal titre. The titre is independent of $\operatorname{PrP}^{\mathrm{C}}$ concentration, i.e., there is no difference between Tga20, Prnp $^{+/+}$and Prnp ${ }^{+/ 0}$ mice. The flowing plateau phase determines the latency to clinical disease onset. The plateau phase is inversely proportional to the $\operatorname{PrP}^{\mathrm{C}}$ concentration. These studies $[157,158]$ demonstrate that propagation and neurotoxicity can be uncoupled, arguing that prions themselves are not directly neurotoxic, supporting claims of previous studies where prions generated by an infected neural graft did not cause degeneration of adjacent $\operatorname{Prnp}^{0 / 0}$ host tissue [22]. Uncoupling of accumulated $\operatorname{PrP}^{\mathrm{Sc}}$ and neurotoxicity was also shown in the model of conditional inactivation of PrP expression in neurons, reversing clinical disease and halting spongiform changes and neuronal loss [107].

\section{Cellular pathways as a response to prion toxicity}

Cellular pathways implicated in misfolded protein response in prion disease can be located on the cellular surface or can be intracellular. $\operatorname{PrP}^{\mathrm{C}}$ molecules with internal deletions (for example, $\Delta 94-134$ and $\Delta 105-125$ ) cause neurodegeneration [165]. The toxicity is more likely caused by abnormal activity on the neuronal surface, for example, interaction with NMDA receptors [77] rather than abnormal folding (discussed in detail in [38]). More relevant to the toxicity of misfolded proteins are intracellular pathways, the ubiquitinproteasome system, and endoplasmic reticulum (ER). Early functional impairment of the ubiquitin-proteasome system to degrade infectious prions has been shown in cell-based in vitro studies [103], in vivo in flies [127], and in transgenic mouse models of the ubiquitin-proteasome system [Fig. 4(6)] [115]. In the conditional knock-out Tg37 mouse 
line and in wild-type mice, accumulation of $\mathrm{PrP}^{\mathrm{Sc}}$ causes sustained over-activation of the PERK/eIF2alpha branch of the cellular defence pathway-unfolded protein response (UPR) with phosphorylation of eIF2alpha [Fig. 4(10)]. This leads to sustained repression of global protein synthesis (translational repression), with subsequent synaptic failure and neuronal loss [126]. The discovery of the involvement of these pathways in prion disease provides a scientific rationale for the pharmacological enhancement of the ubiquitin-proteasome system and to target the ER unfolded protein response pathway in prion disease.

\section{Models to understand the role of the immune system in the spread of prions}

Whilst sporadic forms of prion disease have their origin within the CNS, acquired forms can involve the lymphoreticular system. The transmission of BSE prions through the food chain caused vCJD in humans. A highly distinctive and diagnostic feature of this prion strain was the colonisation of the lymphoreticular system [65], and this has generated widespread interest into the role of the immune system in prion diseases. Prior to the outbreak of vCJD, however, the role of the spleen in modulating neuro-invasion had been studied in scrapie-infected mice [81], where spleen removal reduced efficiency of peripheral prion infection, but had no effect once the infection had reached the CNS. The extensive use of transgenic mice, ectopically expressing prion protein on the lymphoid system or genetically modified immunosuppressed mice, has further pinpointed the role of individual components of the lymphoreticular system in prion spread $[84,85]$. It is thought that prions invade the central nervous system from lymphoid organs by ascending spread via sympathetic and parasympathetic nerves [60,112] and that anchored PrP is an essential component for this pathway [86]. For more detailed reviews on the lymphoid system in prion spread, see [43] and [1]. The importance of the immune system has been successfully shown in preclinical studies with anti-PrP antibodies [194].

\section{Models to investigate potential therapeutic approaches}

The goal of biomedical research is to understand, prevent, and eventually treat human disease. This is no different for prion diseases, and developing effective treatments of prion diseases is a priority for many research teams. Clinical trials have to be evidence-based, and in vitro and in vivo models are essential to identify and characterise pathways that can be therapeutically targeted or can be used to validate "antiprion compounds" in preclinical studies. However, the beneficial effects of compounds or reagents have not yet translated into effective clinical trials in patients [42, 62], but at least have led to important quantitative clinical data.
In silico computational modelling in combination with cell-based screening systems [71] can be the first-line experimental approach to identify potential anti-prion therapeutics. This is usually further validated in animal models, where prion infected mice are challenged with promising candidate drugs $[63,125]$.

The use of monoclonal antibodies has been promising in preventing prion spread and in attenuating and delaying clinical prion disease [194]. These studies were carried out in wild-type mice of a defined genetic background. The safety of the use of monoclonal antibodies, however, has been a matter of considerable debate. Whilst toxicity of concentrated monoclonal antibodies was reported by some researchers [153, 166], others could not reproduce these findings [87], in particular when using physiological concentrations. A widely used transgenic model to assess therapeutic efficacy is the Tga20 mouse line that overexpresses wild-type PrP. For example, in a recent study [63], Tga20 mouse line was used to identify, through iterative cycles of chemical design and synthesis, luminescent conjugated polythiophenes (molecules with high affinity for ordered protein aggregates) as potentially effective antiprion compounds.

The conditional knock-out mouse line Tg37 [107] was used in a study into the effect of a reduction of $\operatorname{PrP}^{\mathrm{C}}$ expression through therapeutic knockdown using RNAi in mice with established prion disease [195]). This model was also used to show positive effects of UPR inhibition by localized hippocampal PrP knockdown and through pharmacological inhibition with the compound GSK2606414 of PERK kinase, a key mediator of the UPR pathway in the endoplasmic reticulum $[125,126]$. The compounds targeting the cellular downstream pathways-for example, PERK kinase inhibitor GSK2606414 causes severe toxicity in mice, making it unlikely that it will make it to a clinical trial in humans.

Given that innovative genetic strategies to halt or reverse progression of neurodegenerative diseases are emerging, it is possible that genetic manipulation with the end-result mimicking naturally occurring protective/prion-resistant single amino-acid substitutions may be a treatment of choice in prion diseases, particularly those of inherited aetiology. Validation and approval of such approaches undoubtedly will require extensive detailed in vitro cellbased and in vivo animal studies in existing and newly generated model systems of prion infection.

\section{Summary}

The development and characterisation of models of prion disease have served a wide range of purposes, which have changed over time. The first models were used to 
understand the transmissible nature of prions, well before even the concept of transmissible proteopathies was born. These models date back to the 1930s [47, 48] and culminated in the demonstration that kuru and CJD are transmissible neurodegenerative diseases in the 1960s [13, 54, 55], leading to the hypothesis that scrapie is caused by an unusual self-replicating agent [61]. Nearly two decades later, using a combination of transmission studies and biochemical evidence, Prusiner formulated the protein-only hypothesis $[21,114,146]$. The availability of genetically engineered mice in the 1980s then opened a wider area of research $[68,148]$ in that functional aspects of PrP and human mutations were modelled. The use of transgenic mice in prion research took-off after the generation of a mouse model devoid of $\mathrm{PrP}^{\mathrm{C}}$, generated by Weissmann's team $[22,27,28,155]$. This model enabled the generation of mice devoid of endogenous PrP and was the basis for systematic modelling structural and functional aspects of $\operatorname{PrP}[20,22,53,190,191]$. These mice were far superior to any previous model system to understand prion strains [2, 45], transmission barriers [184], tissue-specific effects of normal and abnormal PrP [59, 143, 144], the role of deletions, point mutations and modifications [165] affecting structure, and glycosylation [37, 86, 142]. In parallel, powerful cell-based and cell-free in vitro systems have been developed $[88,160]$ and complemented the animal models. As pointed out in the paragraph on therapeutic approaches, the ultimate goal of model systems is to understand, prevent, and treat human prion diseases. Thus, the model systems described in this review are only the beginning of the discovery phase. Whilst these model systems over the decades have become increasingly validated (through the use in several laboratories), they still have to live up to the promises of providing a robust and valid experimental platform that can be used for drug discovery which translates well into a clinical trial.

\section{Perspective (Fig. 6)}

Studies with animal models and cell culture will most likely remain the mainstay in prion disease research for foreseeable future. The use of rat models has been proposed due to advantages related to larger brain size and physiology, including cognitive and behavioural responses somewhat closer to human. However, the greatest potential undoubtedly lies in mouse models. These have proven to be invaluable in prion disease research and it is likely that further
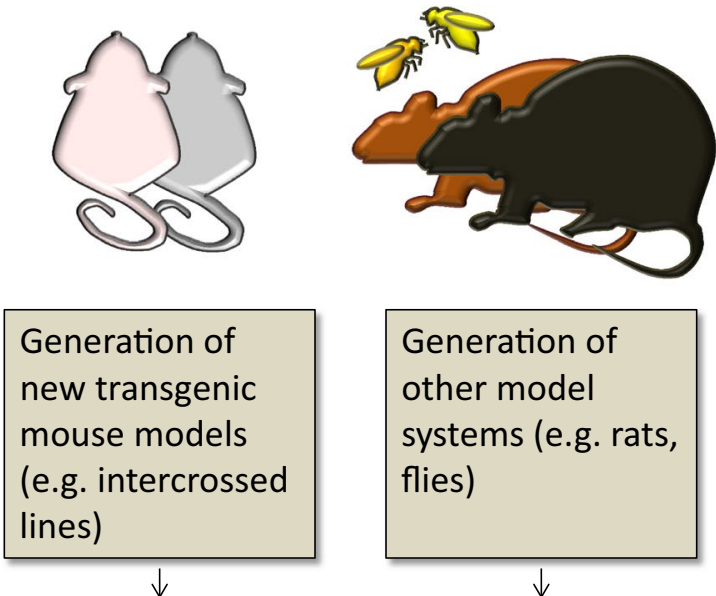
other model systems (e.g. rats, flies)

Physiological function of $\operatorname{PrPC}$

High resolution structure of $\mathrm{PrPC}^{\mathrm{C}}$ and $\operatorname{PrPsc}$

PrPC-PrPSc interaction

Cellular pathways activated / dysregulated by PrPSc

Neurotoxicity

Therapeutic targets and effective and safe anti-prion compounds

Fig. 6 Future perspective in prion disease research: left increasing sophistication of transgenic models, and increasing access to gene editing methodologies is likely to have a significant role also in prion research. Left centre other species, in particular those which are easy to maintain and to manipulate, such as flies may play a role in models, in particular aiming at functional roles of PrP; increasing use of rat models due to the larger brain size. Centre-right a significant potential of induced pluripotent stem cells can be expected, and right in vitro cell-based and cell-free assays will play an important role in diagnostics, epidemiology, and safety of blood products and drug screening 
models will be able to address the increasingly complex questions of prion biology. The discovery of a comparatively straightforward methodology to induce pluripotent stem cells (iPSC) through reprogramming of fibroblasts (Takahashi and Yamanaka 2006) opened new avenues for the study of cellular pathomechanisms, early disease diagnosis, and screening of therapeutic compounds in probably almost all human diseases. Misfolded protein-associated neurodegenerative disorders, such as Parkinson's disease and Alzheimer's disease, are diseases, where iPSC derived from fibroblasts from skin or dura mater have been already actively used in research over the last decade providing novel insights into the molecular biology. Application of the reprogrammed cells in prion research, along with continuous advances in the somatic cell reprogramming techniques, offers a promising tool for deepening the understanding of the molecular biology of prion infection, such as susceptibility, modes and sites (neurones or glia or both) of prion replication, neurotoxicity, effects on cellular function, disease phenotypes and new drug screening, or, indeed, iPSC could serve as therapeutic agent themselves. Finally, significant resources are put into advancing technological and methodological aspects of designing cell-free assays and high-throughput in silico screening methods. The power of bioinformatics and computational chemistry holds promises for the development of high-throughput in silico screening methods, but also are an important development to support the commitment to replacement, reduction, and refinement of animal research.

Acknowledgements Funding was provided by the National Institute of Health Research (NIHR) UCLH/UCL Biomedical Research Centre and Dementia Biomedical Research Unit.

Open Access This article is distributed under the terms of the Creative Commons Attribution 4.0 International License (http://creativecommons.org/licenses/by/4.0/), which permits unrestricted use, distribution, and reproduction in any medium, provided you give appropriate credit to the original author(s) and the source, provide a link to the Creative Commons license, and indicate if changes were made.

\section{References}

1. Aguzzi A, Heppner FL, Heikenwalder M, Prinz M, Mertz K, Seeger H, Glatzel M (2003) Immune system and peripheral nerves in propagation of prions to CNS. Br Med Bull 66:141-159

2. Aguzzi A, Weissmann C (1997) Prion research: the next frontiers. Nature 389:795-798. doi:10.1038/39758

3. Asano M, Mohri S, Ironside JW, Ito M, Tamaoki N, Kitamoto T (2006) vCJD prion acquires altered virulence through trans-species infection. Biochem Biophys Res Commun 342:293-299. doi:10.1016/j.bbrc.2006.01.149

4. Asante EA, Gowland I, Grimshaw A, Linehan JM, Smidak M, Houghton R, Osiguwa O, Tomlinson A, Joiner S, Brandner S et al (2009) Absence of spontaneous disease and comparative prion susceptibility of transgenic mice expressing mutant human prion proteins. J Gen Virol 90:546-558. doi:10.1099/ vir.0.007930-0

5. Asante EA, Grimshaw A, Smidak M, Jakubcova T, Tomlinson A, Jeelani A, Hamdan S, Powell C, Joiner S, Linehan JM et al (2015) Transmission properties of human PrP 102L prions challenge the relevance of mouse models of GSS. PLoS Pathog 11:e1004953. doi:10.1371/journal.ppat.1004953

6. Asante EA, Linehan JM, Desbruslais M, Joiner S, Gowland I, Wood AL, Welch J, Hill AF, Lloyd SE, Wadsworth JD et al (2002) BSE prions propagate as either variant CJD-like or sporadic CJD-like prion strains in transgenic mice expressing human prion protein. EMBO J 21:6358-6366

7. Asante EA, Linehan JM, Gowland I, Joiner S, Fox K, Cooper S, Osiguwa O, Gorry M, Welch J, Houghton R et al (2006) Dissociation of pathological and molecular phenotype of variant Creutzfeldt-Jakob disease in transgenic human prion protein 129 heterozygous mice. Proc Natl Acad Sci USA 103:10759_ 10764. doi:10.1073/pnas.0604292103

8. Asante EA, Linehan JM, Smidak M, Tomlinson A, Grimshaw A, Jeelani A, Jakubcova T, Hamdan S, Powell C, Brandner $\mathrm{S}$ et al (2013) Inherited prion disease A117V is not simply a proteinopathy but produces prions transmissible to transgenic mice expressing homologous prion protein. PLoS Pathog 9:e1003643. doi:10.1371/journal.ppat.1003643

9. Asante EA, Smidak M, Grimshaw A, Houghton R, Tomlinson A, Jeelani A, Jakubcova T, Hamdan S, Richard-Londt A, Linehan JM et al (2015) A naturally occurring variant of the human prion protein completely prevents prion disease. Nature 522:478-481. doi:10.1038/nature 14510

10. Barria MA, Gonzalez-Romero D, Soto C (2012) Cyclic amplification of prion protein misfolding. Methods Mol Biol 849:199212. doi:10.1007/978-1-61779-551-0_14

11. Barria MA, Telling GC, Gambetti P, Mastrianni JA, Soto C (2011) Generation of a new form of human $\operatorname{PrP}(\mathrm{Sc})$ in vitro by interspecies transmission from cervid prions. J Biol Chem 286:7490-7495. doi:10.1074/jbc.M110.198465

12. Basler K, Oesch B, Scott M, Westaway D, Walchli M, Groth DF, McKinley MP, Prusiner SB, Weissmann C (1986) Scrapie and cellular PrP isoforms are encoded by the same chromosomal gene. Cell 46:417-428

13. Beck E, Daniel PM, Alpers M, Gajdusek DC, Gibbs CJ Jr (1966) Experimental "kuru" in chimpanzees. A pathological report. Lancet 2:1056-1059

14. Beck JA, Poulter M, Campbell TA, Adamson G, Uphill JB, Guerreiro R, Jackson GS, Stevens JC, Manji H, Collinge J et al (2010) PRNP allelic series from 19 years of prion protein gene sequencing at the MRC Prion Unit. Hum Mutat 31:E1551E1563. doi: $10.1002 /$ humu.21281

15. Behrens A, Aguzzi A (2002) Small is not beautiful: antagonizing functions for the prion protein $\operatorname{Pr} \mathrm{P}(\mathrm{C})$ and its homologue Dpl. Trends Neurosci 25:150-154

16. Beringue V, Le Dur A, Tixador P, Reine F, Lepourry L, Perret-Liaudet A, Haik S, Vilotte JL, Fontes M, Laude H (2008) Prominent and persistent extraneural infection in human PrP transgenic mice infected with variant CJD. PLoS One 3:e1419. doi:10.1371/journal.pone.0001419

17. Bessen RA, Kocisko DA, Raymond GJ, Nandan S, Lansbury PT, Caughey B (1995) Non-genetic propagation of strain-specific properties of scrapie prion protein. Nature 375:698-700. doi:10.1038/375698a0

18. Bishop MT, Hart P, Aitchison L, Baybutt HN, Plinston C, Thomson V, Tuzi NL, Head MW, Ironside JW, Will RG et al (2006) Predicting susceptibility and incubation time of 
human-to-human transmission of vCJD. Lancet Neurol 5:393398. doi:10.1016/s1474-4422(06)70413-6

19. Bishop MT, Will RG, Manson JC (2010) Defining sporadic Creutzfeldt-Jakob disease strains and their transmission properties. Proc Natl Acad Sci USA 107:12005-12010. doi:10.1073/ pnas. 1004688107

20. Blattler T, Brandner S, Raeber AJ, Klein MA, Voigtlander T, Weissmann C, Aguzzi A (1997) PrP-expressing tissue required for transfer of scrapie infectivity from spleen to brain. Nature 389:69-73. doi:10.1038/37981

21. Bolton DC, McKinley MP, Prusiner SB (1982) Identification of a protein that purifies with the scrapie prion. Science 218:1309-1311

22. Brandner S, Isenmann S, Raeber A, Fischer M, Sailer A, Kobayashi Y, Marino S, Weissmann C, Aguzzi A (1996) Normal host prion protein necessary for scrapie-induced neurotoxicity. Nature 379:339-343. doi:10.1038/379339a0

23. Brandner S, Raeber A, Sailer A, Blattler T, Fischer M, Weissmann C, Aguzzi A (1996) Normal host prion protein (PrPC) is required for scrapie spread within the central nervous system. Proc Natl Acad Sci USA 93:13148-13151

24. Bremer J, Baumann F, Tiberi C, Wessig C, Fischer H, Schwarz P, Steele AD, Toyka KV, Nave KA, Weis J et al (2010) Axonal prion protein is required for peripheral myelin maintenance. Nat Neurosci 13:310-318. doi:10.1038/nn.2483

25. Brown P, Gibbs CJ Jr, Rodgers-Johnson P, Asher DM, Sulima MP, Bacote A, Goldfarb LG, Gajdusek DC (1994) Human spongiform encephalopathy: the National Institutes of Health series of 300 cases of experimentally transmitted disease. Ann Neurol 35:513-529. doi:10.1002/ana.410350504

26. Bruce ME, Will RG, Ironside JW, McConnell I, Drummond D, Suttie A, McCardle L, Chree A, Hope J, Birkett C et al (1997) Transmissions to mice indicate that 'new variant' CJD is caused by the BSE agent. Nature 389:498-501. doi:10.1038/39057

27. Bueler H, Aguzzi A, Sailer A, Greiner RA, Autenried P, Aguet M, Weissmann C (1993) Mice devoid of PrP are resistant to scrapie. Cell 73:1339-1347

28. Bueler H, Fischer M, Lang Y, Bluethmann H, Lipp HP, DeArmond SJ, Prusiner SB, Aguet M, Weissmann C (1992) Normal development and behaviour of mice lacking the neuronal cell-surface PrP protein. Nature 356:577-582. doi: $10.1038 / 356577 \mathrm{a} 0$

29. Cartoni C, Schinina ME, Maras B, Nonno R, Vaccari G, Di Baria MA, Conte M, Liu QG, Lu M, Cardone F et al (2005) Identification of the pathological prion protein allotypes in scrapie-infected heterozygous bank voles (Clethrionomys glareolus) by high-performance liquid chromatography-mass spectrometry. J Chromatogr A 1081:122-126

30. Cassard H, Torres JM, Lacroux C, Douet JY, Benestad SL, Lantier F, Lugan S, Lantier I, Costes P, Aron N et al (2014) Evidence for zoonotic potential of ovine scrapie prions. Nat Commun 5:5821. doi:10.1038/ncomms6821

31. Chandler RL. Encephalopathy in mice. Lancet 279:107-108. doi:10.1016/S0140-6736(62)91769-5

32. Chandler RL (1961) Encephalopathy in mice produced by inoculation with scrapie brain material. Lancet 1:1378-1379

33. Chapuis J, Moudjou M, Reine F, Herzog L, Jaumain E, Chapuis C, Quadrio I, Boulliat J, Perret-Liaudet A, Dron M et al (2016) Emergence of two prion subtypes in ovine PrP transgenic mice infected with human MM2-cortical Creutzfeldt-Jakob disease prions. Acta Neuropathol Commun 4:10. doi:10.1186/ s40478-016-0284-9

34. Chen B, Morales R, Barria MA, Soto C (2010) Estimating prion concentration in fluids and tissues by quantitative PMCA. Nat Methods 7:519-520. doi:10.1038/nmeth.1465
35. Chen B, Soto C, Morales R (2014) Peripherally administrated prions reach the brain at sub-infectious quantities in experimental hamsters. FEBS Lett 588:795-800. doi:10.1016/j. febslet.2014.01.038

36. Chesebro B, Race R, Wehrly K, Nishio J, Bloom M, Lechner D, Bergstrom S, Robbins K, Mayer L, Keith JM et al (1985) Identification of scrapie prion protein-specific mRNA in scrapie-infected and uninfected brain. Nature 315:331-333

37. Chesebro B, Trifilo M, Race R, Meade-White K, Teng C, LaCasse R, Raymond L, Favara C, Baron G, Priola S et al (2005) Anchorless prion protein results in infectious amyloid disease without clinical scrapie. Science 308:1435-1439. doi:10.1126/ science. 1110837

38. Chiesa R (2015) The elusive role of the prion protein and the mechanism of toxicity in prion disease. PLoS Pathog 11:e1004745. doi:10.1371/journal.ppat.1004745

39. Collinge $J$ (2016) Mammalian prions and their wider relevance in neurodegenerative diseases. Nature 539:217-226. doi:10.1038/nature20415

40. Collinge J (1999) Variant Creutzfeldt-Jakob disease. Lancet 354:317-323. doi:10.1016/s0140-6736(99)05128-4

41. Collinge J, Clarke AR (2007) A general model of prion strains and their pathogenicity. Science 318:930-936. doi:10.1126/ science. 1138718

42. Collinge J, Gorham M, Hudson F, Kennedy A, Keogh G, Pal S, Rossor M, Rudge P, Siddique D, Spyer M et al (2009) Safety and efficacy of quinacrine in human prion disease (PRION-1 study): a patient-preference trial. Lancet Neurol 8:334-344

43. Collinge J, Hawke S (1998) B lymphocytes in prion neuroinvasion: central or peripheral players? Nat Med 4:1369-1370. doi:10.1038/3955

44. Collinge J, Palmer MS, Sidle KC, Gowland I, Medori R, Ironside J, Lantos P (1995) Transmission of fatal familial insomnia to laboratory animals. Lancet 346:569-570

45. Collinge J, Sidle KC, Meads J, Ironside J, Hill AF (1996) Molecular analysis of prion strain variation and the aetiology of 'new variant' CJD. Nature 383:685-690. doi: $10.1038 / 383685 \mathrm{a} 0$

46. Comoy EE, Mikol J, Luccantoni-Freire S, Correia E, LescoutraEtchegaray N, Durand V, Dehen C, Andreoletti O, Casalone C, Richt JA et al (2015) Transmission of scrapie prions to primate after an extended silent incubation period. Sci Rep 5:11573. doi:10.1038/srep11573

47. Cuille J, Chelle PL (1939) Experimental transmission of trembling to the goat. C R Seances Acad Sci 208:1058-1160

48. Cuille J, Chelle PL (1936) La maladie dite tremblante du mouton est-elle inoculable? CR Acad Sci (Paris) 203:1552-1554

49. Cuille J, Chelle PL (1938) La tremblante du mouton estelle determinee par un virus filterable? CR Acad Sci (Paris) 206:1687-1688

50. Diack AB, Ritchie DL, Peden AH, Brown D, Boyle A, Morabito L, Maclennan D, Burgoyne P, Jansen C, Knight RS et al (2014) Variably protease-sensitive prionopathy, a unique prion variant with inefficient transmission properties. Emerg Infect Dis 20:1969-1979. doi:10.3201/eid2012.140214

51. Falsig J, Aguzzi A (2008) The prion organotypic slice culture assay-POSCA. Nat Protoc 3:555-562. doi:10.1038/ nprot.2008.13

52. Falsig J, Julius C, Margalith I, Schwarz P, Heppner FL, Aguzzi A (2008) A versatile prion replication assay in organotypic brain slices. Nat Neurosci 11:109-117. doi:10.1038/nn2028

53. Fischer M, Rulicke T, Raeber A, Sailer A, Moser M, Oesch B, Brandner S, Aguzzi A, Weissmann C (1996) Prion protein (PrP) with amino-proximal deletions restoring susceptibility of $\operatorname{PrP}$ knockout mice to scrapie. EMBO J 15:1255-1264 
54. Gajdusek DC, Gibbs CJ, Alpers M (1966) Experimental transmission of a Kuru-like syndrome to chimpanzees. Nature 209:794-796

55. Gajdusek DC, Gibbs CJ Jr, Asher DM, David E (1968) Transmission of experimental kuru to the spider monkey (Ateles geoffreyi). Science 162:693-694

56. Gavin BA, Dolph MJ, Deleault NR, Geoghegan JC, Khurana V, Feany MB, Dolph PJ, Supattapone S (2006) Accelerated accumulation of misfolded prion protein and spongiform degeneration in a Drosophila model of Gerstmann-Straussler-Scheinker syndrome. J Neurose Off J Soc Neurosci 26:12408-12414. doi:10.1523/JNEUROSCI.3372-06.2006

57. Gibbs CJ Jr, Gajdusek DC, Asher DM, Alpers MP, Beck E, Daniel PM, Matthews WB (1968) Creutzfeldt-Jakob disease (spongiform encephalopathy): transmission to the chimpanzee. Science 161:388-389

58. Giles K, De Nicola GF, Patel S, Glidden DV, Korth C, Oehler A, DeArmond SJ, Prusiner SB (2012) Identification of I137M and other mutations that modulate incubation periods for two human prion strains. J Virol 86:6033-6041. doi:10.1128/ JVI.07027-11

59. Glatzel M, Giger O, Braun N, Aguzzi A (2004) The peripheral nervous system and the pathogenesis of prion diseases. Curr Mol Med 4:355-359

60. Glatzel M, Heppner FL, Albers KM, Aguzzi A (2001) Sympathetic innervation of lymphoreticular organs is rate limiting for prion neuroinvasion. Neuron 31:25-34

61. Griffith JS (1967) Self-replication and scrapie. Nature 215:1043-1044

62. Haik S, Marcon G, Mallet A, Tettamanti M, Welaratne A, Giaccone G, Azimi S, Pietrini V, Fabreguettes JR, Imperiale D et al (2014) Doxycycline in Creutzfeldt-Jakob disease: a phase 2, randomised, double-blind, placebo-controlled trial. Lancet Neurol 13:150-158. doi:10.1016/s1474-4422(13)70307-7

63. Herrmann US, Schutz AK, Shirani H, Huang D, Saban D, Nuvolone M, Li B, Ballmer B, Aslund AK, Mason JJ et al (2015) Structure-based drug design identifies polythiophenes as antiprion compounds. Sci Transl Med 7:299ra123. doi:10.1126/ scitranslmed.aab1923

64. Hill AF, Desbruslais M, Joiner S, Sidle KC, Gowland I, Collinge J, Doey LJ, Lantos P (1997) The same prion strain causes vCJD and BSE. Nature 389:448-450, 526. doi:10.1038/38925

65. Hill AF, Zeidler M, Ironside J, Collinge J (1997) Diagnosis of new variant Creutzfeldt-Jakob disease by tonsil biopsy. Lancet 349:99-100. doi:10.1016/S0140-6736(97)24002-X

66. Hizume M, Kobayashi A, Teruya K, Ohashi H, Ironside JW, Mohri S, Kitamoto T (2009) Human prion protein (PrP) 219K is converted to PrPSc but shows heterozygous inhibition in variant Creutzfeldt-Jakob disease infection. J Biol Chem 284:36033609. doi:10.1074/jbc.M809254200

67. Hsiao K, Baker HF, Crow TJ, Poulter M, Owen F, Terwilliger JD, Westaway D, Ott J, Prusiner SB (1989) Linkage of a prion protein missense variant to Gerstmann-Straussler syndrome. Nature 338:342-345. doi:10.1038/338342a0

68. Hsiao K, Dlouhy SR, Farlow MR, Cass C, Da Costa M, Conneally PM, Hodes ME, Ghetti B, Prusiner SB (1992) Mutant prion proteins in Gerstmann-Straussler-Scheinker disease with neurofibrillary tangles. Nat Genet 1:68-71. doi:10.1038/ ng0492-68

69. Hsiao KK, Groth D, Scott M, Yang SL, Serban H, Rapp D, Foster D, Torchia M, Dearmond SJ, Prusiner SB (1994) Serial transmission in rodents of neurodegeneration from transgenic mice expressing mutant prion protein. Proc Natl Acad Sci USA 91:9126-9130

70. Hsiao KK, Scott M, Foster D, Groth DF, DeArmond SJ, Prusiner SB (1990) Spontaneous neurodegeneration in transgenic mice with mutant prion protein. Science 250:1587-1590

71. Hyeon JW, Choi J, Kim SY, Govindaraj RG, Jam Hwang K, Lee YS, An SS, Lee MK, Joung JY, No KT et al (2015) Discovery of novel anti-prion compounds using in silico and in vitro approaches. Sci Rep 5:14944. doi:10.1038/srep14944

72. Jackson GS, Burk-Rafel J, Edgeworth JA, Sicilia A, Abdilahi S, Korteweg J, Mackey J, Thomas C, Wang G, Schott JM et al (2014) Population screening for variant Creutzfeldt-Jakob disease using a novel blood test: diagnostic accuracy and feasibility study. JAMA neurology 71:421-428. doi:10.1001/ jamaneurol.2013.6001

73. Jackson WS, Borkowski AW, Watson NE, King OD, Faas H, Jasanoff A, Lindquist S (2013) Profoundly different prion diseases in knock-in mice carrying single PrP codon substitutions associated with human diseases. Proc Natl Acad Sci USA 110:14759-14764. doi:10.1073/pnas. 1312006110

74. Jansen C, Voet W, Head MW, Parchi P, Yull H, Verrips A, Wesseling P, Meulstee J, Baas F, van Gool WA et al (2011) A novel seven-octapeptide repeat insertion in the prion protein gene (PRNP) in a Dutch pedigree with Gerstmann-StrausslerScheinker disease phenotype: comparison with similar cases from the literature. Acta Neuropathol 121:59-68. doi:10.1007/ s00401-010-0656-3

75. Jendroska K, Heinzel FP, Torchia M, Stowring L, Kretzschmar HA, Kon A, Stern A, Prusiner SB, DeArmond SJ (1991) Proteinase-resistant prion protein accumulation in Syrian hamster brain correlates with regional pathology and scrapie infectivity. Neurology 41:1482-1490

76. Jones EM, Surewicz WK (2005) Fibril conformation as the basis of species- and strain-dependent seeding specificity of mammalian prion amyloids. Cell 121:63-72. doi:10.1016/j. cell.2005.01.034

77. Khosravani H, Zhang Y, Tsutsui S, Hameed S, Altier C, Hamid J, Chen L, Villemaire M, Ali Z, Jirik FR et al (2008) Prion protein attenuates excitotoxicity by inhibiting NMDA receptors. J Cell Biol 181:551-565. doi:10.1083/jcb.200711002

78. Kimberlin RH, Cole S, Walker CA (1987) Temporary and permanent modifications to a single strain of mouse scrapie on transmission to rats and hamsters. J Gen Virol 68(Pt 7):18751881. doi:10.1099/0022-1317-68-7-1875

79. Kimberlin RH, Walker CA (1978) Evidence that the transmission of one source of scrapie agent to hamsters involves separation of agent strains from a mixture. J Gen Virol 39:487-496. doi:10.1099/0022-1317-39-3-487

80. Kimberlin RH, Walker CA (1986) Pathogenesis of scrapie (strain $263 \mathrm{~K}$ ) in hamsters infected intracerebrally, intraperitoneally or intraocularly. J Gen Virol 67(Pt 2):255-263. doi:10.1099/0022-1317-67-2-255

81. Kimberlin RH, Walker CA (1989) The role of the spleen in the neuroinvasion of scrapie in mice. Virus Res 12:201-211

82. Kitamoto T, Nakamura K, Nakao K, Shibuya S, Shin RW, Gondo Y, Katsuki M, Tateishi J (1996) Humanized prion protein knock-in by Cre-induced site-specific recombination in the mouse. Biochem Biophys Res Commun 222:742-747. doi:10.1006/bbrc.1996.0814

83. Kitamoto T, Tateishi J, Sawa H, Doh-Ura K (1989) Positive transmission of Creutzfeldt-Jakob disease verified by murine kuru plaques. Lab Invest J Tech Methods Pathol 60:507-512

84. Klein MA, Frigg R, Flechsig E, Raeber AJ, Kalinke U, Bluethmann H, Bootz F, Suter M, Zinkernagel RM, Aguzzi A (1997) A crucial role for B cells in neuroinvasive scrapie. Nature 390:687-690. doi:10.1038/37789

85. Klein MA, Frigg R, Raeber AJ, Flechsig E, Hegyi I, Zinkernagel RM, Weissmann C, Aguzzi A (1998) PrP expression in B 
lymphocytes is not required for prion neuroinvasion. Nat Med 4:1429-1433. doi:10.1038/4022

86. Klingeborn M, Race B, Meade-White KD, Rosenke R, Striebel JF, Chesebro B (2011) Crucial role for prion protein membrane anchoring in the neuroinvasion and neural spread of prion infection. J Virol 85:1484-1494. doi:10.1128/JVI.02167-10

87. Klohn PC, Farmer M, Linehan JM, O'Malley C, Fernandez de Marco M, Taylor W, Farrow M, Khalili-Shirazi A, Brandner S, Collinge J (2012) PrP antibodies do not trigger mouse hippocampal neuron apoptosis. Science 335:52. doi:10.1126/ science. 1215579

88. Klohn PC, Stoltze L, Flechsig E, Enari M, Weissmann C (2003) A quantitative, highly sensitive cell-based infectivity assay for mouse scrapie prions. Proc Natl Acad Sci USA 100:1166611671. doi:10.1073/pnas.1834432100

89. Kobayashi A, Asano M, Mohri S, Kitamoto T (2007) Crosssequence transmission of sporadic Creutzfeldt-Jakob disease creates a new prion strain. J Biol Chem 282:30022-30028. doi:10.1074/jbc.M704597200

90. Kobayashi A, Matsuura Y, Mohri S, Kitamoto T (2014) Distinct origins of dura mater graft-associated Creutzfeldt-Jakob disease: past and future problems. Acta Neuropathol Commun 2:32. doi:10.1186/2051-5960-2-32

91. Kobayashi A, Parchi P, Yamada M, Brown P, Saverioni D, Matsuura Y, Takeuchi A, Mohri S, Kitamoto T (2015) Transmission properties of atypical Creutzfeldt-Jakob disease: a clue to disease etiology? J Virol 89:3939-3946. doi:10.1128/ JVI.03183-14

92. Kobayashi A, Parchi P, Yamada M, Mohri S, Kitamoto T (2015) Neuropathological and biochemical criteria to identify acquired Creutzfeldt-Jakob disease among presumed sporadic cases. Neuropathol Off J Jpn Soc Neuropathol. doi:10.1111/ neup. 12270

93. Kobayashi A, Sakuma N, Matsuura Y, Mohri S, Aguzzi A, Kitamoto $T$ (2010) Experimental verification of a traceback phenomenon in prion infection. J Virol 84:3230-3238. doi:10.1128/ JVI.02387-09

94. Kocisko DA, Come JH, Priola SA, Chesebro B, Raymond GJ, Lansbury PT, Caughey B (1994) Cell-free formation of protease-resistant prion protein. Nature 370:471-474. doi:10.1038/370471a0

95. Kocisko DA, Priola SA, Raymond GJ, Chesebro B, Lansbury PT Jr, Caughey B (1995) Species specificity in the cellfree conversion of prion protein to protease-resistant forms: a model for the scrapie species barrier. Proc Natl Acad Sci USA 92:3923-3927

96. Kong Q, Huang S, Zou W, Vanegas D, Wang M, Wu D, Yuan J, Zheng M, Bai H, Deng H et al (2005) Chronic wasting disease of elk: transmissibility to humans examined by transgenic mouse models. J Neurosci Off J Soc Neurosci 25:7944-7949. doi:10.1523/JNEUROSCI.2467-05.2005

97. Kuczius T, Groschup MH (1999) Differences in proteinase K resistance and neuronal deposition of abnormal prion proteins characterize bovine spongiform encephalopathy (BSE) and scrapie strains. Mol Med 5:406-418

98. Kuffer A, Lakkaraju AK, Mogha A, Petersen SC, Airich K, Doucerain C, Marpakwar R, Bakirci P, Senatore A, Monnard A et al (2016) The prion protein is an agonistic ligand of the G protein-coupled receptor Adgrg6. Nature. doi:10.1038/nature19312

99. Kundu B, Maiti NR, Jones EM, Surewicz KA, Vanik DL, Surewicz WK (2003) Nucleation-dependent conformational conversion of the Y145Stop variant of human prion protein: structural clues for prion propagation. Proc Natl Acad Sci USA 100:12069-12074. doi:10.1073/pnas.2033281100
100. Lasmezas CI, Comoy E, Hawkins S, Herzog C, Mouthon F, Konold T, Auvre F, Correia E, Lescoutra-Etchegaray N, Sales $\mathrm{N}$ et al (2005) Risk of oral infection with bovine spongiform encephalopathy agent in primates. Lancet 365:781-783. doi:10.1016/s0140-6736(05)17985-9

101. Lasmezas CI, Deslys JP, Demaimay R, Adjou KT, Lamoury F, Dormont D, Robain O, Ironside J, Hauw JJ (1996) BSE transmission to macaques. Nature 381:743-744. doi:10.1038/381743a0

102. Legname G, Baskakov IV, Nguyen HO, Riesner D, Cohen FE, DeArmond SJ, Prusiner SB (2004) Synthetic mammalian prions. Science 305:673-676. doi:10.1126/science.1100195

103. Lehman NL (2009) The ubiquitin proteasome system in neuropathology. Acta Neuropathol 118:329-347. doi:10.1007/ s00401-009-0560-x

104. Lescoutra-Etchegaray N, Jaffre N, Sumian C, Durand V, Correia E, Mikol J, Luccantoni-Freire S, Culeux A, Deslys JP, Comoy EE (2015) Evaluation of the protection of primates transfused with variant Creutzfeldt-Jakob disease-infected blood products filtered with prion removal devices: a 5-year update. Transfusion 55:1231-1241. doi:10.1111/trf.12999

105. Mahal SP, Baker CA, Demczyk CA, Smith EW, Julius C, Weissmann C (2007) Prion strain discrimination in cell culture: the cell panel assay. Proc Natl Acad Sci USA 104:2090820913. doi:10.1073/pnas.0710054104

106. Mallucci G, Collinge J (2005) Rational targeting for prion therapeutics. Nat Rev Neurosci 6:23-34. doi:10.1038/nrn1584

107. Mallucci G, Dickinson A, Linehan J, Klohn PC, Brandner S, Collinge J (2003) Depleting neuronal PrP in prion infection prevents disease and reverses spongiosis. Science 302:871-874. doi:10.1126/science.1090187

108. Mallucci GR, Ratte S, Asante EA, Linehan J, Gowland I, Jefferys JG, Collinge J (2002) Post-natal knockout of prion protein alters hippocampal CA1 properties, but does not result in neurodegeneration. EMBO J 21:202-210. doi:10.1093/ emboj/21.3.202

109. Manson JC, Clarke AR, Hooper ML, Aitchison L, McConnell I, Hope J (1994) 129/Ola mice carrying a null mutation in PrP that abolishes mRNA production are developmentally normal. Mol Neurobiol 8:121-127. doi:10.1007/BF02780662

110. Manson JC, Jamieson E, Baybutt H, Tuzi NL, Barron R, McConnell I, Somerville R, Ironside J, Will R, Sy MS et al (1999) A single amino acid alteration (101L) introduced into murine PrP dramatically alters incubation time of transmissible spongiform encephalopathy. EMBO J 18:6855-6864. doi:10.1093/ emboj/18.23.6855

111. Mastrianni JA, Nixon R, Layzer R, Telling GC, Han D, DeArmond SJ, Prusiner SB (1999) Prion protein conformation in a patient with sporadic fatal insomnia. N Engl J Med 340:16301638. doi:10.1056/nejm199905273402104

112. McBride PA, Schulz-Schaeffer WJ, Donaldson M, Bruce M, Diringer H, Kretzschmar HA, Beekes M (2001) Early spread of scrapie from the gastrointestinal tract to the central nervous system involves autonomic fibers of the splanchnic and vagus nerves. J Virol 75:9320-9327. doi:10.1128/ JVI.75.19.9320-9327.2001

113. McGuire LI, Peden AH, Orru CD, Wilham JM, Appleford NE, Mallinson G, Andrews M, Head MW, Caughey B, Will RG et al (2012) Real time quaking-induced conversion analysis of cerebrospinal fluid in sporadic Creutzfeldt-Jakob disease. Ann Neurol 72:278-285. doi:10.1002/ana.23589

114. McKinley MP, Bolton DC, Prusiner SB (1983) A proteaseresistant protein is a structural component of the scrapie prion. Cell 35:57-62 
115. McKinnon C, Goold R, Andre R, Devoy A, Ortega Z, Moonga J, Linehan JM, Brandner S, Lucas JJ, Collinge J et al (2016) Prion-mediated neurodegeneration is associated with early impairment of the ubiquitin-proteasome system. Acta Neuropathol 131:411-425. doi:10.1007/s00401-015-1508-y

116. Mead S (2006) Prion disease genetics. Eur J Human Genet EJHG 14:273-281. doi:10.1038/sj.ejhg.5201544

117. Mead S, Beck J, Dickinson A, Fisher EM, Collinge J (2000) Examination of the human prion protein-like gene doppel for genetic susceptibility to sporadic and variant Creutzfeldt-Jakob disease. Neurosci Lett 290:117-120

118. Mead S, Poulter M, Beck J, Webb TE, Campbell TA, Linehan JM, Desbruslais M, Joiner S, Wadsworth JD, King A et al (2006) Inherited prion disease with six octapeptide repeat insertional mutation-molecular analysis of phenotypic heterogeneity. Brain J Neurol 129:2297-2317. doi:10.1093/brain/awl226

119. Mead S, Stumpf MP, Whitfield J, Beck JA, Poulter M, Campbell T, Uphill JB, Goldstein D, Alpers M, Fisher EM et al (2003) Balancing selection at the prion protein gene consistent with prehistoric kurulike epidemics. Science 300:640-643

120. Mead S, Whitfield J, Poulter M, Shah P, Uphill J, Campbell T, Al-Dujaily H, Hummerich H, Beck J, Mein CA et al (2009) A novel protective prion protein variant that colocalizes with kuru exposure. N Engl J Med 361:2056-2065. doi:10.1056/ NEJMoa0809716

121. Meier P, Genoud N, Prinz M, Maissen M, Rulicke T, Zurbriggen A, Raeber AJ, Aguzzi A (2003) Soluble dimeric prion protein binds $\operatorname{PrP}(\mathrm{Sc})$ in vivo and antagonizes prion disease. Cell 113:49-60

122. Moda F, Suardi S, Di Fede G, Indaco A, Limido L, Vimercati C, Ruggerone M, Campagnani I, Langeveld J, Terruzzi A et al (2012) MM2-thalamic Creutzfeldt-Jakob disease: neuropathological, biochemical and transmission studies identify a distinctive prion strain. Brain Pathol 22:662-669. doi:10.1111/j.1750-3639.2012.00572.x

123. Monari L, Chen SG, Brown P, Parchi P, Petersen RB, Mikol J, Gray F, Cortelli P, Montagna P, Ghetti B et al (1994) Fatal familial insomnia and familial Creutzfeldt-Jakob disease: different prion proteins determined by a DNA polymorphism. Proc Natl Acad Sci USA 91:2839-2842

124. Moore RC, Lee IY, Silverman GL, Harrison PM, Strome R, Heinrich C, Karunaratne A, Pasternak SH, Chishti MA, Liang Y et al (1999) Ataxia in prion protein (PrP)-deficient mice is associated with upregulation of the novel PrP-like protein doppel. J Mol Biol 292:797-817. doi:10.1006/jmbi.1999.3108

125. Moreno JA, Halliday M, Molloy C, Radford H, Verity N, Axten JM, Ortori CA, Willis AE, Fischer PM, Barrett DA et al (2013) Oral treatment targeting the unfolded protein response prevents neurodegeneration and clinical disease in prioninfected mice. Science Transl Med 5:206ra138. doi:10.1126/ scitranslmed. 3006767

126. Moreno JA, Radford H, Peretti D, Steinert JR, Verity N, Martin MG, Halliday M, Morgan J, Dinsdale D, Ortori CA et al (2012) Sustained translational repression by eIF2alpha-P mediates prion neurodegeneration. Nature 485:507-511. doi:10.1038/ nature 11058

127. Murali A, Maue RA, Dolph PJ (2014) Reversible symptoms and clearance of mutant prion protein in an inducible model of a genetic prion disease in Drosophila melanogaster. Neurobiol Dis 67:71-78. doi:10.1016/j.nbd.2014.03.013

128. Nonno R, Di Bari MA, Cardone F, Vaccari G, Fazzi P, Dell'Omo G, Cartoni C, Ingrosso L, Boyle A, Galeno R et al (2006) Efficient transmission and characterization of Creutzfeldt-Jakob disease strains in bank voles. PLoS Pathog 2:e12. doi:10.1371/ journal.ppat.0020012
129. Notari S, Xiao X, Espinosa JC, Cohen Y, Qing L, Aguilar-Calvo P, Kofskey D, Cali I, Cracco L, Kong Q et al (2014) Transmission characteristics of variably protease-sensitive prionopathy. Emerg Infect Dis 20:2006-2014. doi:10.3201/eid2012.140548

130. Nuvolone M, Hermann M, Sorce S, Russo G, Tiberi C, Schwarz P, Minikel E, Sanoudou D, Pelczar P, Aguzzi A (2016) Strictly coisogenic C57BL/6J-Prnp-/- mice: a rigorous resource for prion science. J Exp Med 213:313-327. doi:10.1084/jem.20151610

131. Oesch B, Westaway D, Walchli M, McKinley MP, Kent SB, Aebersold R, Barry RA, Tempst P, Teplow DB, Hood LE et al (1985) A cellular gene encodes scrapie PrP 27-30 protein. Cell 40:735-746

132. Owen F, Poulter M, Lofthouse R, Collinge J, Crow TJ, Risby D, Baker HF, Ridley RM, Hsiao K, Prusiner SB (1989) Insertion in prion protein gene in familial Creutzfeldt-Jakob disease. Lancet 1:51-52

133. Pagadala NS, Perez-Pineiro R, Wishart DS, Tuszynski JA (2015) In silico studies and fluorescence binding assays of potential anti-prion compounds reveal an important binding site for prion inhibition from $\operatorname{PrP}(\mathrm{C})$ to $\operatorname{PrP}(\mathrm{Sc})$. Eur $\mathrm{J}$ Med Chem 91:118-131. doi:10.1016/j.ejmech.2014.07.045

134. Palmiter RD, Brinster RL, Hammer RE, Trumbauer ME, Rosenfeld MG, Birnberg NC, Evans RM (1982) Dramatic growth of mice that develop from eggs microinjected with metallothionein-growth hormone fusion genes. Nature 300:611-615

135. Parchi P, Cescatti M, Notari S, Schulz-Schaeffer WJ, Capellari S, Giese A, Zou WQ, Kretzschmar H, Ghetti B, Brown P (2010) Agent strain variation in human prion disease: insights from a molecular and pathological review of the National Institutes of Health series of experimentally transmitted disease. Brain J Neurol 133:3030-3042. doi:10.1093/brain/awq234

136. Parchi P, Giese A, Capellari S, Brown P, Schulz-Schaeffer W, Windl O, Zerr I, Budka H, Kopp N, Piccardo P et al (1999) Classification of sporadic Creutzfeldt-Jakob disease based on molecular and phenotypic analysis of 300 subjects. Ann Neurol 46:224-233

137. Pattison IH (1966) The relative susceptibility of sheep, goats and mice to two types of the goat scrapie agent. Res Vet Sci $7: 207-212$

138. Pattison IH (1972) Scrapie-a personal view. J Clin Pathol Suppl (R Coll Pathol) 6:110-114

139. Peoc'h K, Levavasseur E, Delmont E, De Simone A, LaffontProust I, Privat N, Chebaro Y, Chapuis C, Bedoucha P, Brandel JP et al (2012) Substitutions at residue 211 in the prion protein drive a switch between CJD and GSS syndrome, a new mechanism governing inherited neurodegenerative disorders. Hum Mol Genet 21:5417-5428. doi:10.1093/hmg/dds377

140. Piccardo P, Manson JC, King D, Ghetti B, Barron RM (2007) Accumulation of prion protein in the brain that is not associated with transmissible disease. Proc Natl Acad Sci USA 104:47124717. doi:10.1073/pnas.0609241104

141. Pirisinu L, Di Bari MA, D’Agostino C, Marcon S, Riccardi G, Poleggi A, Cohen ML, Appleby BS, Gambetti P, Ghetti B et al (2016) Gerstmann-Straussler-Scheinker disease subtypes efficiently transmit in bank voles as genuine prion diseases. Sci Rep 6:20443. doi:10.1038/srep20443

142. Piro JR, Harris BT, Nishina K, Soto C, Morales R, Rees JR, Supattapone S (2009) Prion protein glycosylation is not required for strain-specific neurotropism. J Virol 83:5321-5328. doi:10.1128/jvi.02502-08

143. Prinz M, Huber G, Macpherson AJ, Heppner FL, Glatzel M, Eugster HP, Wagner N, Aguzzi A (2003) Oral prion infection requires normal numbers of Peyer's patches but not of enteric lymphocytes. Am J Pathol 162:1103-1111. doi:10.1016/ S0002-9440(10)63907-7 
144. Prinz M, Montrasio F, Furukawa H, van der Haar ME, Schwarz P, Rulicke T, Giger OT, Hausler KG, Perez D, Glatzel M et al (2004) Intrinsic resistance of oligodendrocytes to prion infection. J Neurosci Off J Soc Neurosci 24:5974-5981. doi:10.1523/ JNEUROSCI.0122-04.2004

145. Priola SA, Chabry J, Chan K (2001) Efficient conversion of normal prion protein ( $\mathrm{PrP}$ ) by abnormal hamster PrP is determined by homology at amino acid residue 155 . J Virol 75:4673-4680. doi:10.1128/JVI.75.10.4673-4680.2001

146. Prusiner SB (1982) Novel proteinaceous infectious particles cause scrapie. Science 216:136-144

147. Prusiner SB, Groth DF, Cochran SP, Masiarz FR, McKinley MP, Martinez HM (1980) Molecular properties, partial purification, and assay by incubation period measurements of the hamster scrapie agent. Biochemistry 19:4883-4891

148. Prusiner SB, Scott M, Foster D, Pan KM, Groth D, Mirenda C, Torchia M, Yang SL, Serban D, Carlson GA et al (1990) Transgenetic studies implicate interactions between homologous PrP isoforms in scrapie prion replication. Cell 63:673-686

149. Race B, Meade-White KD, Miller MW, Barbian KD, Rubenstein R, LaFauci G, Cervenakova L, Favara C, Gardner D, Long D et al (2009) Susceptibilities of nonhuman primates to chronic wasting disease. Emerg Infect Dis 15:1366-1376. doi:10.3201/ eid1509.090253

150. Race RE, Fadness LH, Chesebro B (1987) Characterization of scrapie infection in mouse neuroblastoma cells. J Gen Virol 68(Pt 5):1391-1399. doi:10.1099/0022-1317-68-5-1391

151. Radovanovic I, Braun N, Giger OT, Mertz K, Miele G, Prinz M, Navarro B, Aguzzi A (2005) Truncated prion protein and Doppel are myelinotoxic in the absence of oligodendrocytic PrPC. J Neurosci Off J Soc Neurosci 25:4879-4888. doi:10.1523/ JNEUROSCI.0328-05.2005

152. Raeber AJ, Race RE, Brandner S, Priola SA, Sailer A, Bessen RA, Mucke L, Manson J, Aguzzi A, Oldstone MB et al (1997) Astrocyte-specific expression of hamster prion protein (PrP) renders PrP knockout mice susceptible to hamster scrapie. EMBO J 16:6057-6065. doi:10.1093/emboj/16.20.6057

153. Reimann RR, Sonati T, Hornemann S, Herrmann US, Arand M, Hawke S, Aguzzi A (2016) Differential toxicity of antibodies to the prion protein. PLoS Pathog 12:e1005401. doi:10.1371/journal.ppat.1005401

154. Rossi D, Cozzio A, Flechsig E, Klein MA, Rulicke T, Aguzzi A, Weissmann C (2001) Onset of ataxia and Purkinje cell loss in PrP null mice inversely correlated with $\mathrm{Dpl}$ level in brain. EMBO J 20:694-702. doi:10.1093/emboj/20.4.694

155. Sailer A, Bueler H, Fischer M, Aguzzi A, Weissmann C (1994) No propagation of prions in mice devoid of PrP. Cell 77:967-968

156. Sakaguchi S, Katamine S, Nishida N, Moriuchi R, Shigematsu K, Sugimoto T, Nakatani A, Kataoka Y, Houtani T, Shirabe S et al (1996) Loss of cerebellar Purkinje cells in aged mice homozygous for a disrupted PrP gene. Nature 380:528-531. doi:10.1038/380528a0

157. Sandberg MK, Al-Doujaily H, Sharps B, Clarke AR, Collinge J (2011) Prion propagation and toxicity in vivo occur in two distinct mechanistic phases. Nature 470:540-542. doi:10.1038/ nature09768

158. Sandberg MK, Al-Doujaily H, Sharps B, De Oliveira MW, Schmidt C, Richard-Londt A, Lyall S, Linehan JM, Brandner S, Wadsworth JD et al (2014) Prion neuropathology follows the accumulation of alternate prion protein isoforms after infective titre has peaked. Nat Commun 5:4347. doi:10.1038/ ncomms 5347

159. Sandberg MK, Al-Doujaily H, Sigurdson CJ, Glatzel M, O'Malley C, Powell C, Asante EA, Linehan JM, Brandner S, Wadsworth JD et al (2010) Chronic wasting disease prions are not transmissible to transgenic mice overexpressing human prion protein. J Gen Virol 91:2651-2657. doi:10.1099/ vir.0.024380-0

160. Sawyer EB, Edgeworth JA, Thomas C, Collinge J, Jackson GS (2015) Preclinical detection of infectivity and disease-specific PrP in blood throughout the incubation period of prion disease. Sci Rep 5:17742. doi:10.1038/srep17742

161. Schmidt C, Fizet J, Properzi F, Batchelor M, Sandberg MK, Edgeworth JA, Afran L, Ho S, Badhan A, Klier S et al (2015) A systematic investigation of production of synthetic prions from recombinant prion protein. Open Biol 5:150165. doi:10.1098/ rsob. 150165

162. Schmitz M, Cramm M, Llorens F, Muller-Cramm D, Collins S, Atarashi R, Satoh K, Orru CD, Groveman BR, Zafar S et al (2016) The real-time quaking-induced conversion assay for detection of human prion disease and study of other protein misfolding diseases. Nat Protoc 11:2233-2242. doi:10.1038/ nprot.2016.120

163. Scott M, Foster D, Mirenda C, Serban D, Coufal F, Walchli M, Torchia M, Groth D, Carlson G, DeArmond SJ et al (1989) Transgenic mice expressing hamster prion protein produce species-specific scrapie infectivity and amyloid plaques. Cell 59:847-857

164. Scott MR, Peretz D, Nguyen HO, Dearmond SJ, Prusiner SB (2005) Transmission barriers for bovine, ovine, and human prions in transgenic mice. J Virol 79:5259-5271. doi:10.1128/ JVI.79.9.5259-5271.2005

165. Shmerling D, Hegyi I, Fischer M, Blattler T, Brandner S, Gotz J, Rulicke T, Flechsig E, Cozzio A, von Mering C et al (1998) Expression of amino-terminally truncated PrP in the mouse leading to ataxia and specific cerebellar lesions. Cell 93:203-214

166. Solforosi L, Criado JR, McGavern DB, Wirz S, Sanchez-Alavez M, Sugama S, DeGiorgio LA, Volpe BT, Wiseman E, Abalos G et al (2004) Cross-linking cellular prion protein triggers neuronal apoptosis in vivo. Science 303:1514-1516. doi:10.1126/ science. 1094273

167. Sorce S, Nuvolone M, Keller A, Falsig J, Varol A, Schwarz P, Bieri M, Budka H, Aguzzi A (2014) The role of the NADPH oxidase NOX2 in prion pathogenesis. PLoS Pathog 10:e1004531. doi:10.1371/journal.ppat.1004531

168. Striebel JF, Race B, Meade-White KD, LaCasse R, Chesebro B (2011) Strain specific resistance to murine scrapie associated with a naturally occurring human prion protein polymorphism at residue 171. PLoS Pathog 7:e1002275. doi:10.1371/journal. ppat. 1002275

169. Takahashi K, Yamanaka S (2006) Induction of pluripotent stem cells from mouse embryonic and adult fibroblast cultures by defined factors. Cell 126: 663-676. doi:10.1016/j. cell.2006.07.024

170. Tamguney G, Giles K, Bouzamondo-Bernstein E, Bosque PJ, Miller MW, Safar J, DeArmond SJ, Prusiner SB (2006) Transmission of elk and deer prions to transgenic mice. J Virol 80:9104-9114. doi:10.1128/jvi.00098-06

171. Tanaka M, Chien P, Yonekura K, Weissman JS (2005) Mechanism of cross-species prion transmission: an infectious conformation compatible with two highly divergent yeast prion proteins. Cell 121:49-62. doi:10.1016/j.cell.2005.03.008

172. Tateishi J, Brown P, Kitamoto T, Hoque ZM, Roos R, Wollman R, Cervenakova L, Gajdusek DC (1995) First experimental transmission of fatal familial insomnia. Nature 376:434-435. doi:10.1038/376434a0

173. Telling GC, Parchi P, DeArmond SJ, Cortelli P, Montagna P, Gabizon R, Mastrianni J, Lugaresi E, Gambetti P, Prusiner SB (1996) Evidence for the conformation of the pathologic isoform of the prion protein enciphering and propagating prion diversity. Science 274:2079-2082 
174. Telling GC, Scott M, Hsiao KK, Foster D, Yang SL, Torchia M, Sidle KC, Collinge J, DeArmond SJ, Prusiner SB (1994) Transmission of Creutzfeldt-Jakob disease from humans to transgenic mice expressing chimeric human-mouse prion protein. Proc Natl Acad Sci USA 91:9936-9940

175. Telling GC, Scott M, Mastrianni J, Gabizon R, Torchia M, Cohen FE, DeArmond SJ, Prusiner SB (1995) Prion propagation in mice expressing human and chimeric PrP transgenes implicates the interaction of cellular PrP with another protein. Cell 83:79-90

176. Tessier PM, Lindquist S (2007) Prion recognition elements govern nucleation, strain specificity and species barriers. Nature 447:556-561. doi:10.1038/nature05848

177. Thackray AM, Andreoletti O, Bujdoso R (2016) Bioassay of prion-infected blood plasma in PrP transgenic Drosophila. Biochem J. doi:10.1042/bcj20160417

178. Thackray AM, Muhammad F, Zhang C, Denyer M, Spiropoulos J, Crowther DC, Bujdoso R (2012) Prion-induced toxicity in PrP transgenic Drosophila. Exp Mol Pathol 92:194-201. doi:10.1016/j.yexmp.2012.01.005

179. Tobler I, Gaus SE, Deboer T, Achermann P, Fischer M, Rulicke T, Moser M, Oesch B, McBride PA, Manson JC (1996) Altered circadian activity rhythms and sleep in mice devoid of prion protein. Nature 380:639-642. doi:10.1038/380639a0

180. van der Merwe J, Aiken J, Westaway D, McKenzie D (2015) The standard scrapie cell assay: development, utility and prospects. Viruses 7:180-198. doi:10.3390/v7010180

181. Vanik DL, Surewicz KA, Surewicz WK (2004) Molecular basis of barriers for interspecies transmissibility of mammalian prions. Mol Cell 14:139-145

182. Wadsworth JD, Asante EA, Collinge J (2010) Review: contribution of transgenic models to understanding human prion disease. Neuropathol Appl Neurobiol 36:576-597. doi:10.1111/j.1365-2990.2010.01129.x

183. Wadsworth JD, Asante EA, Desbruslais M, Linehan JM, Joiner S, Gowland I, Welch J, Stone L, Lloyd SE, Hill AF et al (2004) Human prion protein with valine 129 prevents expression of variant CJD phenotype. Science 306:1793-1796. doi:10.1126/ science. 1103932

184. Wadsworth JD, Jackson GS, Hill AF, Collinge J (1999) Molecular biology of prion propagation. Curr Opin Genet Dev 9:338-345

185. Wadsworth JD, Joiner S, Linehan JM, Cooper S, Powell C, Mallinson G, Buckell J, Gowland I, Asante EA, Budka H et al (2006) Phenotypic heterogeneity in inherited prion disease (P102L) is associated with differential propagation of proteaseresistant wild-type and mutant prion protein. Brain $\mathbf{J}$ Neurol 129:1557-1569. doi:10.1093/brain/aw1076
186. Wadsworth JD, Joiner S, Linehan JM, Desbruslais M, Fox K, Cooper S, Cronier S, Asante EA, Mead S, Brandner S et al (2008) Kuru prions and sporadic Creutzfeldt-Jakob disease prions have equivalent transmission properties in transgenic and wild-type mice. Proc Natl Acad Sci USA 105:3885-3890. doi:10.1073/pnas.0800190105

187. Watts JC, Giles K, Bourkas ME, Patel S, Oehler A, Gavidia M, Bhardwaj S, Lee J, Prusiner SB (2016) Towards authentic transgenic mouse models of heritable PrP prion diseases. Acta Neuropathol. doi:10.1007/s00401-016-1585-6

188. Watts JC, Giles K, Patel S, Oehler A, DeArmond SJ, Prusiner SB (2014) Evidence that bank vole PrP is a universal acceptor for prions. PLoS Pathog 10:e1003990. doi:10.1371/journal.ppat.1003990

189. Watts JC, Giles K, Stohr J, Oehler A, Bhardwaj S, Grillo SK, Patel S, DeArmond SJ, Prusiner SB (2012) Spontaneous generation of rapidly transmissible prions in transgenic mice expressing wild-type bank vole prion protein. Proc Natl Acad Sci USA 109:3498-3503. doi:10.1073/pnas.1121556109

190. Weissmann C, Bueler H (2004) A mouse to remember. Cell 116:S111-S113 (112 p following S113)

191. Weissmann C, Fischer M, Raeber A, Bueler H, Sailer A, Shmerling D, Rulicke T, Brandner S, Aguzzi A (1998) The use of transgenic mice in the investigation of transmissible spongiform encephalopathies. Revue scientifique et technique (International Office of Epizootics) 17:278-290

192. Wenborn A, Terry C, Gros N, Joiner S, D'Castro L, Panico S, Sells J, Cronier S, Linehan JM, Brandner S et al (2015) A novel and rapid method for obtaining high titre intact prion strains from mammalian brain. Sci Rep 5:10062. doi:10.1038/ srep 10062

193. Westaway D, DeArmond SJ, Cayetano-Canlas J, Groth D, Foster D, Yang SL, Torchia M, Carlson GA, Prusiner SB (1994) Degeneration of skeletal muscle, peripheral nerves, and the central nervous system in transgenic mice overexpressing wild-type prion proteins. Cell 76:117-129

194. White AR, Enever P, Tayebi M, Mushens R, Linehan J, Brandner S, Anstee D, Collinge J, Hawke S (2003) Monoclonal antibodies inhibit prion replication and delay the development of prion disease. Nature 422:80-83. doi:10.1038/nature01457

195. White MD, Farmer M, Mirabile I, Brandner S, Collinge J, Mallucci GR (2008) Single treatment with RNAi against prion protein rescues early neuronal dysfunction and prolongs survival in mice with prion disease. Proc Natl Acad Sci USA 105:1023810243. doi:10.1073/pnas.0802759105

196. Zhu C, Herrmann US, Falsig J, Abakumova I, Nuvolone M, Schwarz P, Frauenknecht K, Rushing EJ, Aguzzi A (2016) A neuroprotective role for microglia in prion diseases. J Exp Med 213:1047-1059. doi:10.1084/jem.20151000 